\title{
Inhibition of Pyramidal Neurons in the Basal Amygdala Promotes Fear Learning
}

\author{
Megan Tipps, ㅌzequiel Marron Fernandez de Velasco, Allee Schaeffer, and ${ }^{\circledR}$ Kevin Wickman
}

https://doi.org/10.1523/ENEURO.0272-18.2018

Department of Pharmacology, University of Minnesota, Minneapolis, Minnesota 55455

\begin{abstract}
The basolateral amygdala complex, which contains the lateral (LA) and basal (BA) subnuclei, is a critical substrate of associative learning related to reward and aversive stimuli. Auditory fear conditioning studies in rodents have shown that the excitation of LA pyramidal neurons, driven by the inhibition of local GABAergic interneurons, is critical to fear memory formation. Studies examining the role of the BA in auditory fear conditioning, however, have yielded divergent outcomes. Here, we used a neuron-specific chemogenetic approach to manipulate the excitability of mouse BA neurons during auditory fear conditioning. We found that chemogenetic inhibition of BA GABA neurons, but not BA pyramidal neurons, impaired fear learning. Further, either chemogenetic stimulation of BA GABA neurons or chemogenetic inhibition of BA pyramidal neurons was sufficient to generate the formation of an association between a behavior and a neutral auditory cue. This chemogenetic memory required presentation of a discrete cue, and was not attributable to an effect of BA pyramidal neuron inhibition on general freezing behavior, locomotor activity, or anxiety. Collectively, these data suggest that BA GABA neuron activation and the subsequent inhibition of BA pyramidal neurons play important role in fear learning. Moreover, the roles of inhibitory signaling differ between the LA and BA, with excitation of pyramidal neurons promoting memory formation in the former, and inhibition of pyramidal neurons playing this role in the latter.
\end{abstract}

Key words: basal amygdala; DREADD; fear conditioning; inhibitory signaling; learning and memory

\section{Significance Statement}

The basolateral amygdala complex, which consists of lateral (LA) and basal (BA) subnuclei, is a critical substrate of associative learning. Although inhibition of GABAergic interneurons and subsequent disinhibition of pyramidal neurons in the LA is critical to fear learning, the contribution of the BA is less clear. Here, we used a chemogenetic approach to manipulate pyramidal and GABA neuron excitability in the BA during fear conditioning. We found that BA GABA neuron activity is necessary for fear learning, and that BA GABA neuron stimulation or BA pyramidal neuron inhibition can induce an association between a behavior and an auditory cue. These findings expand our understanding of the fear learning circuitry and highlight a novel role for inhibitory signaling.

\section{Introduction}

Abnormal associative learning is a hallmark of many mental health disorders, including obsessive compulsive disorder, post-traumatic stress disorder, and drug addiction (Nielen et al., 2009; Maren et al., 2013; Bowers and Ressler, 2015; Taylor and Torregrossa, 2015). These
Received July 13, 2018; accepted October 12, 2018; First published October 19, 2018.

Author contributions: M.T., E.M.F.d.V., and K.W. designed research; M.T., E.M.F.d.V., and A.S. performed research; M.T. and E.M.F.d.V. analyzed data; M.T. and K.W. wrote the paper.

The authors declare no competing financial interests.
This work was supported by NIH Grants to M.T. (AA025978) and K.W. (MH061933, DA034696). We thank Nicholas Carlblom for his exceptional care of the mouse colony and Zhillian Xia for all genotyping work.

Correspondence should be addressed to Dr. Megan Tipps, Department of Pharmacology, University of Minnesota, 6-120 Jackson Hall, 321 Church Street Southeast, Minneapolis, MN 55455. E-mail: metipps@gmail.com. 
disorders are characterized by the aberrant establishment of associations between two stimuli or a stimulus and behavior, or the failure to extinguish associations that are no longer relevant. This can result in exaggerated or inappropriate emotional responses, as well as prolonged maladaptive behaviors that persist despite negative consequences. Understanding the neuronal mechanisms that support the formation and durability of associative memories is key to developing effective therapies for diseases in which associative learning is disrupted.

The amygdala has been studied extensively for its role in the formation and extinction of emotional memories and motivated behaviors (LeDoux, 2000; Janak and Tye, 2015). Much of what is known regarding the mechanisms within the amygdala that underlie associative learning derives from Pavlovian fear conditioning studies (Maren, 2001; Fanselow and Poulos, 2005; Pape and Pare, 2010; Johansen et al., 2011; Maren et al., 2013). Fear conditioning is a task in which an aversive unconditioned stimulus [(US) such as a footshock], is paired with a neutral conditioned stimulus [(CS) often an auditory cue], leading to a learned association between the US and CS (Izquierdo et al., 2016). Following fear conditioning, presentation of the originally neutral CS evokes a fearful response. Fear conditioning studies in both animal models and humans have consistently highlighted the importance of the amygdala to the formation and extinction of fear memories (LeDoux, 2000; Pape and Pare, 2010; Johansen et al., 2011; Janak and Tye, 2015), including identifying specific roles for the various subnuclei of the amygdala in these processes (Duvarci and Pare, 2014; Herry and Johansen, 2014).

The basolateral amygdala (BLA) complex is a key input region of the amygdala and a critical substrate of fear memory formation (Duvarci and Pare, 2014; Janak and Tye, 2015). The BLA complex contains lateral (LA) and basal (BA) subdomains (Sah et al., 2003), and data suggest that each domain makes distinct contributions to fear learning. The LA is a node of convergence for thalamic and sensory input related to conditioned and unconditioned stimuli (LeDoux et al., 1990; Romanski et al., 1993; McDonald, 1998). Lesions of the LA disrupt fear learning (LeDoux et al., 1990; Amorapanth et al., 2000; Goosens and Maren, 2001; Nader et al., 2001; Calandreau et al., 2005), and targeted optogenetic studies have shown that LA pyramidal neuron excitation is a critical step in the acquisition of fear memories (Johansen et al., 2010; Yiu et al., 2014). Moreover, the level of excitability of LA pyramidal neurons correlates with the likelihood that they are included in the fear memory trace (Zhou et al., 2009; Kim et al., 2014). Interestingly, the strength of local inhibitory input to LA pyramidal neurons bi-directionally regulates the strength of fear memories. Indeed, the disinhibition of LA pyramidal neurons, driven by the US-mediated inhibition of

https://doi.org/10.1523/ENEURO.0272-18.2018

Copyright (C) 2018 Tipps et al.

This is an open-access article distributed under the terms of the Creative Commons Attribution 4.0 International license, which permits unrestricted use, distribution and reproduction in any medium provided that the original work is properly attributed. parvalbumin interneurons, has been implicated in the gating of fear memory formation (Wolff et al., 2014; Letzkus et al., 2015).

The BA receives glutamatergic input from the LA (Krettek and Price, 1978; Smith and Paré, 1994), as well as from the ventral hippocampus (vHPC) and medial prefrontal cortex (mPFC; Maren et al., 2013; Zelikowsky et al., 2014; Rozeske et al., 2015; McDonald and Mott, 2017). Although connections with the vHPC and mPFC are consistent with its role in contextual fear learning and in the expression of fear memories (Goosens and Maren, 2001; Calandreau et al., 2005; Amano et al., 2011; Akagi Jordão et al., 2015), the relevance of the BA to the acquisition of fear memories is less clear (Goosens and Maren, 2001; Nader et al., 2001; Anglada-Figueroa and Quirk, 2005). To address this issue, we used a neuron-specific chemogenetic approach to probe the relevance of BA pyramidal and GABA neurons to auditory fear conditioning. Our data show that BA GABA neuron activity is necessary for auditory fear conditioning, and that either the stimulation of BA GABA neurons or inhibition of BA pyramidal neurons is sufficient to induce an association between a behavior and a neutral auditory cue.

\section{Materials and Methods}

\section{Animals}

Animal experiments were approved by the University of Minnesota Institutional Animal Care and Use Committee. CaMKIICre [B6.Cg-Tg(Camk2a-cre)T29-1StI/J] and GADCre (B6N.Cg-Gad2 $\left.{ }^{\text {tm2(cre)Zjh }} / \mathrm{J}\right)$ lines were purchased from The Jackson Laboratory, and have been maintained by backcrossing against the C57BL/6J strain. Offspring from these crosses were used to generate the $\mathrm{Cre}(+)$ and $\mathrm{Cre}(-)$ mice used in this study. The generation of conditional CaMKIICre(+):Girk1 $1^{f / f l}$ mice was described previously (Marron Fernandez de Velasco et al., 2017). Unless specifically noted, males and females were used in all experiments, and groups were balanced by sex. All mice were maintained on a $12 \mathrm{~h}$ light/dark cycle, and were provided ad libitum access to food and water.

\section{Reagents}

Picrotoxin (PTX), kynurenic acid, and barium chloride were purchased from Sigma-Aldrich. Clozapine-n-oxide (CNO) and tetrodotoxin (TTX) were purchased from Tocris Bioscience.

\section{Intracranial viral manipulations}

AAV8-hSyn-DIO-hM4Di-mCherry and AAV8-hSyn-DIOhM3Dq-mCherry were purchased from the UNC Vector Core. Mice (7-8 weeks old) were placed in a stereotaxic device (David Kopf Instruments) under isoflurane anesthesia. Microinjectors were made by affixing a 33-gauge stainless steel hypodermic tube within a shorter 26-gauge stainless steel hypodermic tube. The microinjectors were attached to polyethylene-20 tubing affixed to $10 \mu \mathrm{l} \mathrm{Ham}$ ilton syringes, and were lowered through burr holes in the skull to the BA (from bregma: $-1.65 \mathrm{~mm} \mathrm{~A} / \mathrm{P}, \pm 3.25 \mathrm{~mm}$ $\mathrm{M} / \mathrm{L},-4.7 \mathrm{~mm} \mathrm{D} / \mathrm{V}$ ) or LA (from bregma: $-1.6 \mathrm{~mm} \mathrm{~A} / \mathrm{P}$, $\pm 3.3 \mathrm{~mm} \mathrm{M} / \mathrm{L},-4.2 \mathrm{~mm} \mathrm{D} / \mathrm{V}) ; 500 \mathrm{nl}\left(4-7 \times 10^{12}\right.$ viral 
particles $/ \mathrm{ml}$ ) of viral solution per side was injected over 5 min. The syringe was left in place for 10 min following infusion to reduce solution backflow along the infusion track. Subsequent electrophysiological and behavioral experiments were performed 4 weeks after surgery to allow for full recovery and viral expression. The scope and accuracy of viral targeting was assessed by tracking viralmediated mCherry fluorescence in serial coronal sections Cre(+) mice. Fluorescence was observed along the full rostrocaudal axis of the BLA complex. Only data from mice in which the majority $(>80 \%)$ of expression was confined to the targeted subregion (LA or BA), with limited or no diffusion to adjacent structures (i.e., central amygdala or cortex), were analyzed.

\section{Slice electrophysiology}

Coronal slices $(270-280 \mu \mathrm{m})$ containing the BLA complex were prepared from mice (5-12 weeks), as described previously (Arora et al., 2010; Hearing et al., 2013; Marron Fernandez de Velasco et al., 2017), and were incubated at $32^{\circ} \mathrm{C}$ in ACSF for $>30$ min before recording. All measured and command potentials factored in a junction potential $(-15 \mathrm{mV})$ predicted using JPCalc software (Molecular Devices). Agonist-induced somatodendritic currents were measured in an ACSF bath using a K-gluconate pipette solution, at a holding potential $\left(V_{\text {hold }}\right)$ of $-60 \mathrm{mV}$. Holding current, input resistance, and series resistance values were monitored during each experiment by tracking responses to periodic $(0.2 \mathrm{~Hz})$ voltage steps $(-5 \mathrm{mV}, 800$ $\mathrm{ms})$. Only experiments with stable ( $<20 \%$ variation) and low series resistances $(<30 \mathrm{M} \Omega$ ) were analyzed. For rheobase assessments, cells were held in current-clamp mode and given $1 \mathrm{~s}$ current pulses, beginning at $-60 \mathrm{pA}$ and progressing in $20 \mathrm{pA}$ increments until spiking was elicited. Miniature IPSCs (mIPSCs) were recorded $\left(\mathrm{V}_{\text {hold }}=-70\right.$ $\mathrm{mV}$ ) for $1.5 \mathrm{~min}$ using a $140 \mathrm{~mm} \mathrm{CsCl}$-based pipette solution, with 2 mm kynurenic acid and $0.5 \mu \mathrm{M}$ TTX present in the bath to block ionotropic glutamatergic activity and action potentials, respectively. mIPSCs were analyzed with Minianalysis software (Synaptosoft), using a 10 pA detection threshold. All electrophysiological datasets include data from at least two offspring from different breeder pairs.

\section{Behavioral testing}

Adult mice (8-12 weeks) were evaluated using established delay fear conditioning (Tipps et al., 2014) and elevated plus maze (EPM) tasks (Victoria et al., 2016). For fear conditioning experiments, the CS was a $65 \mathrm{~dB}$ white noise (30 s) and the US was a $0.5 \mathrm{~mA}$ footshock (2 s), administered during the last $2 \mathrm{~s}$ of the CS presentation. Before training, mice were exposed to the fear conditioning room and pre-handled for $2 \mathrm{~d}$ to acclimate animals to the behavioral room and investigator. Four conditioning protocols were used in this study: (1) 3 CS/3 US: mice were exposed to three CS-US pairings, with CS presentations separated by $90 \mathrm{~s}$ (7.5 min total); (2) $3 \mathrm{CS} / 0$ US: mice were exposed to the CS three times using the same timing sequence as with the $3 \mathrm{CS} / 3$ US protocol, but no US was delivered (7.5 min total); (3) 0 CS/0 US: mice were placed in the chambers but were not exposed to either CS or US (7.5 min total); and (4) $1 \mathrm{CS} / 1$ US: mice were exposed to a single CS-US pairing, preceded and followed by $90 \mathrm{~s}$ intervals ( $3.5 \mathrm{~min}$ total). To assess context learning ( $24 \mathrm{~h}$ after training), mice were returned to the conditioning chambers and freezing was evaluated for 5 min. To assess cue learning ( $48 \mathrm{~h}$ after training), chambers were reconfigured using a white plastic insert to cover the bar floor and a black tent insert to alter the size, shape, and color of the chambers. Inserts were cleaned with $0.1 \%$ acetic acid to provide a distinct olfactory cue. Freezing was monitored throughout the $15 \mathrm{~min}$ cue recall test period, divided into $5 \times 3$ min bins that included $2 \times$ 3 min CS presentations (Tipps et al., 2014). Freezing behavior, along with measures of average and maximum motion, was assessed automatically using Video Freeze v2.6.1.72 software (Med Associates). For EPM studies, time spent in open and closed arms, and number of arm entries, were recorded for 5 min, beginning when the mouse made its first entry into any arm. EPM performance was scored manually, by an experienced investigator.

\section{Data analysis}

Data are presented throughout as the mean \pm SEM. Statistical analyses were performed using Prism 6 (GraphPad Software) and SigmaPlot 11.0 (Systat Software). Sex was included as a variable in initial analyses. Because no impact of sex was observed in any study, all data from male and female subjects were pooled. Pooled data were analyzed by Student's $t$ test or repeated-measures ANOVA, as appropriate. Pairwise comparisons were performed using Bonferroni or Holms-Sidak $(\mathrm{H}-\mathrm{S})$ tests, when appropriate. For all statistical comparisons, differences were considered significant if $p<0.05$.

\section{Results}

\section{Chemogenetic inhibition of BA GABA neurons impairs auditory fear conditioning}

The BLA complex contains two primary neuron types: the more abundant (85\%) glutamatergic pyramidal neurons that project to several brain regions (Sah et al., 2003; Pape and Pare, 2010), and the less abundant (15\%) GABA interneurons that regulate the excitability of pyramidal neurons (Spampanato et al., 2011). We used a transgenic Cre approach and a Cre-dependent inhibitory chemogenetic viral vector (AAV8-hSyn-DIO-hM4Di-mCherry) to facilitate neuron-specific chemogenetic inhibition of BA pyramidal or GABA neurons. To drive Cre-dependent expression of hM4Di in pyramidal neurons, we used the well characterized CaMKIICre transgenic mouse line, which promotes Cre-dependent recombination in pyramidal neurons in many brain regions (Tsien et al., 1996; Sonner et al., 2005; Madisen et al., 2010; Victoria et al., 2016), including pyramidal neurons in the BLA complex (Wolff et al., 2014; Marron Fernandez de Velasco et al., 2017). To target BA GABA neurons, we used GADCre mice, in which Cre-dependent recombination is evident in all major interneuron subtypes throughout the central nervous system (Taniguchi et al., 2011). Visual comparison of viral-driven fluorescence revealed that AAV8-hSyn-DIOhM4Di-mCherry treatment highlighted a less abundant 

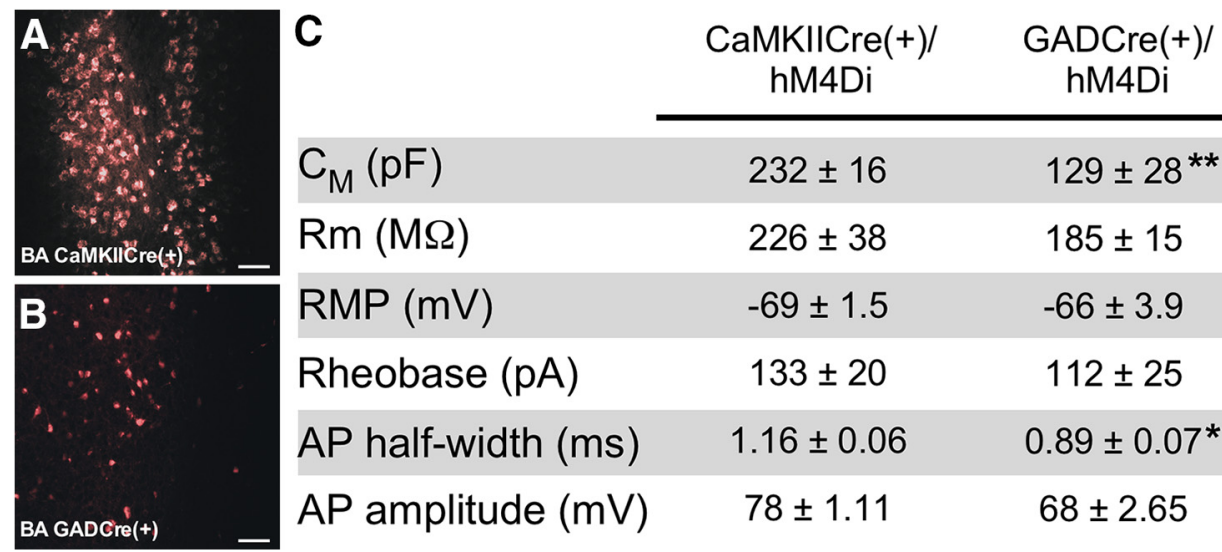

$\begin{array}{lcc}\mathrm{C}_{\mathrm{M}}(\mathrm{pF}) & 232 \pm 16 & 129 \pm 28^{* *} \\ \mathrm{Rm}(\mathrm{M} \Omega) & 226 \pm 38 & 185 \pm 15 \\ \mathrm{RMP}(\mathrm{mV}) & -69 \pm 1.5 & -66 \pm 3.9 \\ \text { Rheobase }(\mathrm{pA}) & 133 \pm 20 & 112 \pm 25 \\ \text { AP half-width }(\mathrm{ms}) & 1.16 \pm 0.06 & 0.89 \pm 0.07^{*} \\ \text { AP amplitude (mV) } & 78 \pm 1.11 & 68 \pm 2.65\end{array}$

Figure 1. Chemogenetic manipulation of BA pyramidal and GABA neurons. $\boldsymbol{A}, \boldsymbol{B}, \mathrm{hM} 4 \mathrm{Di}-\mathrm{mCherry}$ fluorescence in the BA of CaMKIICre(+) and GADCre(+) mice, 4 weeks after infusion of AAV8-hSyn-DIO-hM4Di-mCherry. Scale bar, $20 \mu \mathrm{m}$. $\boldsymbol{C}$, Summary of intrinsic and active electrophysiological properties of hM4Di-expressing BA neurons from CaMKIICre(+) and GADCre $(+)$ mice, 4 weeks after intra-BA infusion of AAV8-hSyn-DIO-hM4Di-mCherry. Apparent capacitance $\left(\mathrm{C}_{\mathrm{M}}\right)$, input/membrane resistance $(\mathrm{Rm})$, and resting membrane potential (RMP) were extracted on achieving whole-cell access. Action potential (AP) characteristics, including threshold (rheobase), half-width, and amplitude, were extracted from the initial spike evoked at rheobase. hM4Di-expressing neurons from GADCre $(+)$ mice had significantly smaller membrane capacitance $\left(t_{(15)}=3.3, * * p=0.005\right)$ and AP half-widths $\left(t_{(15)}=2.9, * p=0.01\right)$ compared to hM4Di-expressing neurons from CaMKIICre $(+)$ mice ( $n=8-15$ neurons/group, derived from at least 3 mice/group).

neuron population, with smaller somata, in GADCre $(+)$ compared to CaMKIICre(+) mice (Fig. $1 A, B$ ). Consistent with published reports (Rainnie et al., 1993; Sosulina et al., 2006; Bocchio et al., 2015), hM4Di-positive neurons in slices from GADCre $(+)$ mice (putative GABA neurons) had significantly smaller apparent capacitances and shorter action potential half-widths than hM4Di-positive neurons from $\mathrm{CaMKIICre}(+)$ mice (putative pyramidal neurons; Fig. 1C). Thus, CaMKIICre(+) and GADCre(+) mice permit the targeted manipulation of distinct populations of neurons in the BA, with morphologic and electrophysiological properties consistent with those reported previously for BLA complex pyramidal and GABA neurons, respectively.

To test the efficacy of the neuron-specific chemogenetic approach, we first examined whether chemogenetic inhibition of LA pyramidal neurons could disrupt auditory fear learning. Previous work has shown that optogenetic inhibition of LA pyramidal neurons disrupted auditory fear conditioning (Johansen et al., 2014), a key line of evidence supporting the contention that LA pyramidal neuron excitation is critical to fear learning. We targeted the LA of CaMKIICre(+) mice with an AAV8-hSyn-DIO-hM4DimCherry virus, and observed robust hM4Di expression 4 weeks later (Fig. 2A,B). Application of the hM4Di agonist CNO $(10 \mu \mathrm{M})$ to acutely isolated slices from these mice reduced the excitability (i.e., increased the rheobase) of hM4Di-expressing LA pyramidal neurons (Fig. 2C,D). We next evaluated viral-treated CaMKIICre(+) and CaMKIICre(-) littermates in an amygdala-dependent delay fear conditioning protocol involving three pairings of an auditory cue/CS and footshock/US (3 CS/3 US; Fanselow and LeDoux, 1999; LeDoux, 2000; Nonaka et al., 2014). All subjects received CNO (2 mg/kg, .i.p.) $30 \mathrm{~min}$ before training, to promote inhibition of hM4Di-expressing neurons during the early (acquisition and consolidation) stages of fear learning (Roth, 2016). Context and cue recall testing oc- curred 24 and $48 \mathrm{~h}$ after training, respectively, in the absence of CNO. All subjects received the same viral and CNO treatments, and because CNO was only administered before training, any phenotypes observed during recall tests were interpreted as reflecting an impact of the neuron-specific manipulation on long-term fear memory formation. As predicted based on previous optogenetic inhibition experiments (Johansen et al., 2014), chemogenetic inhibition of LA pyramidal neurons during training impaired fear memory formation, as evidenced by decreased freezing during both the context and cue recall tests (Fig. 2E). Using the same approach to target BA pyramidal neurons in $\mathrm{CaMKIICre(+)} \mathrm{mice} \mathrm{(Fig.} 2 F, G$ ), we observed that CNO also reduced the excitability (increased the rheobase) of hM4Di-expressing BA pyramidal neurons (Fig. $2 H, I)$. Chemogenetic inhibition of BA pyramidal neurons. Although the $\mathrm{CaMKIICre}(+)$ mice showed increased freezing to the third CS presentation during training, there was no difference in recall for either the auditory cue or associated context in the $3 \mathrm{CS} / 3$ US paradigm (Fig. 2J). Thus, inhibition of BA pyramidal neurons during training did not impair long-term memory formation.

The ability of LA pyramidal neuron inhibition to impair memory formation is consistent with previous reports; however, the lack of effect of BA pyramidal neuron inhibition on fear learning suggests that inhibitory signaling may play a different role in this region. To probe the impact of local GABA-mediated inhibitory signaling within the BA on fear learning, we expressed hM4Di in the BA of GADCre $(+)$ mice (Fig. $3 A$ ). As expected, CNO reduced the excitability (increased the rheobase) of hM4Di-expressing BA GABA neurons in slices from $\operatorname{GADCre}(+)$ subjects (Fig. $3 B, C)$. In contrast to our results in BA pyramidal neurons, chemogenetic inhibition of BA GABA neurons during training significantly impaired fear memory formation, as illustrated by reduced freezing during the context 


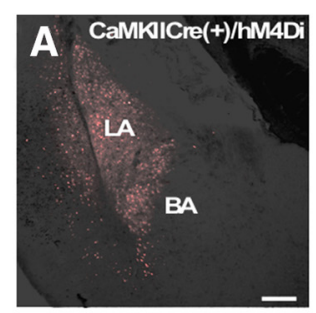

C

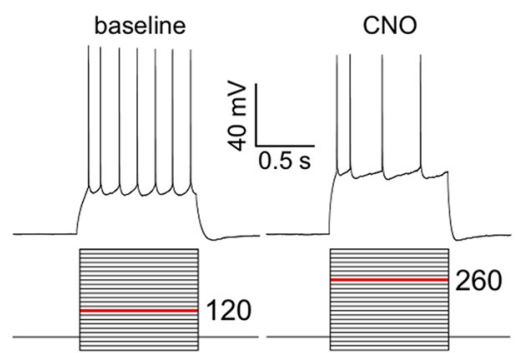

E $100-1 \square$ CaMKIICre(-)/hM4Di
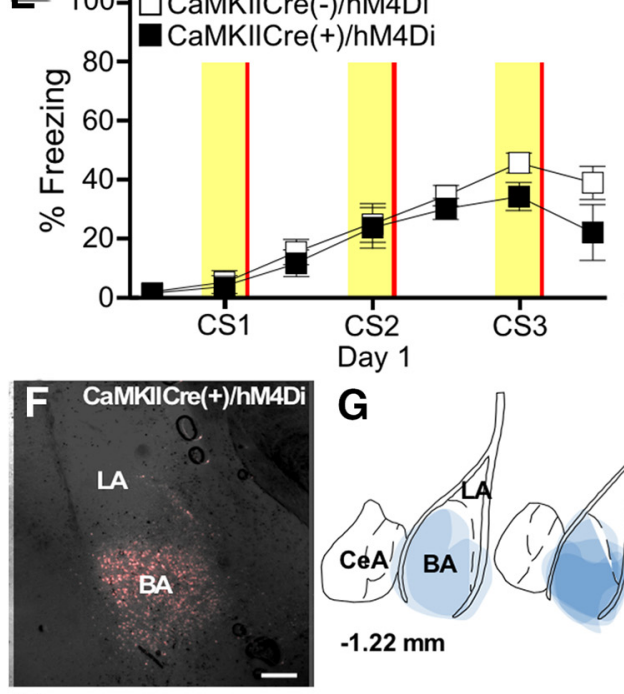

G
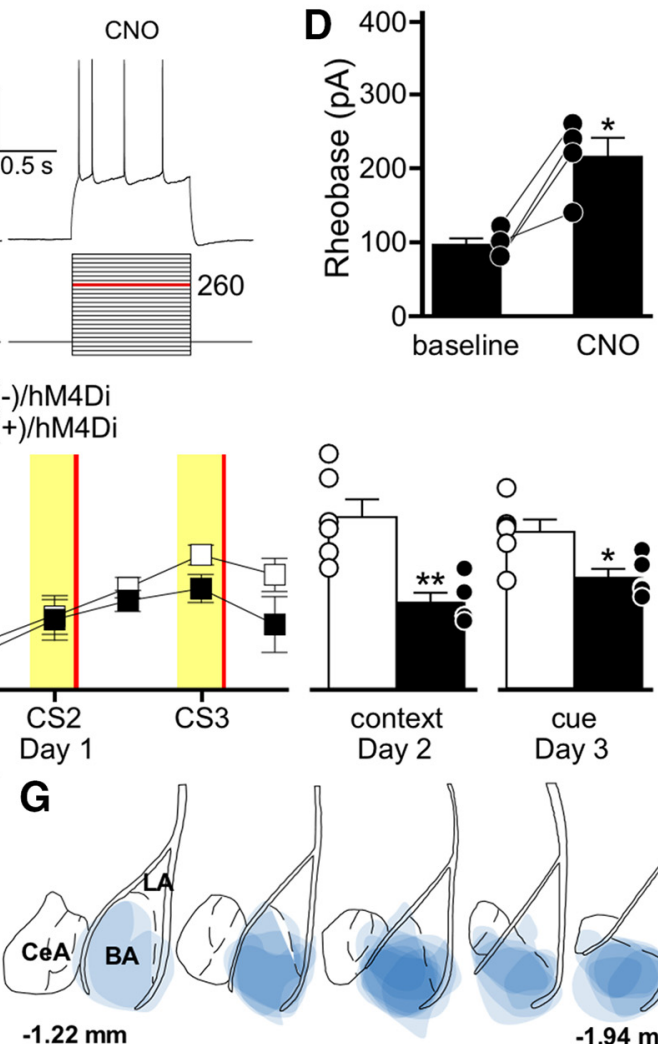

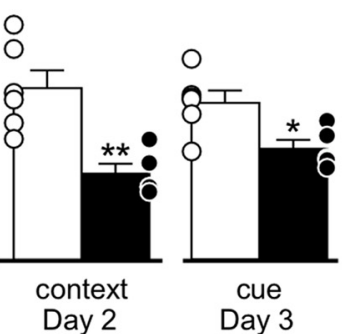

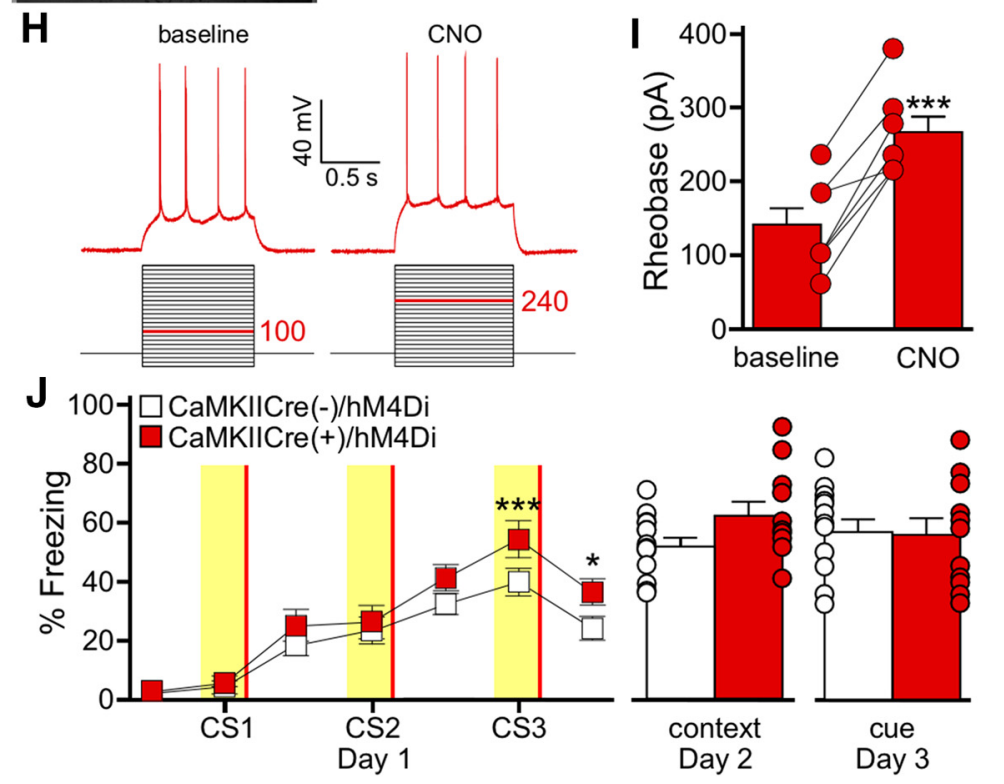
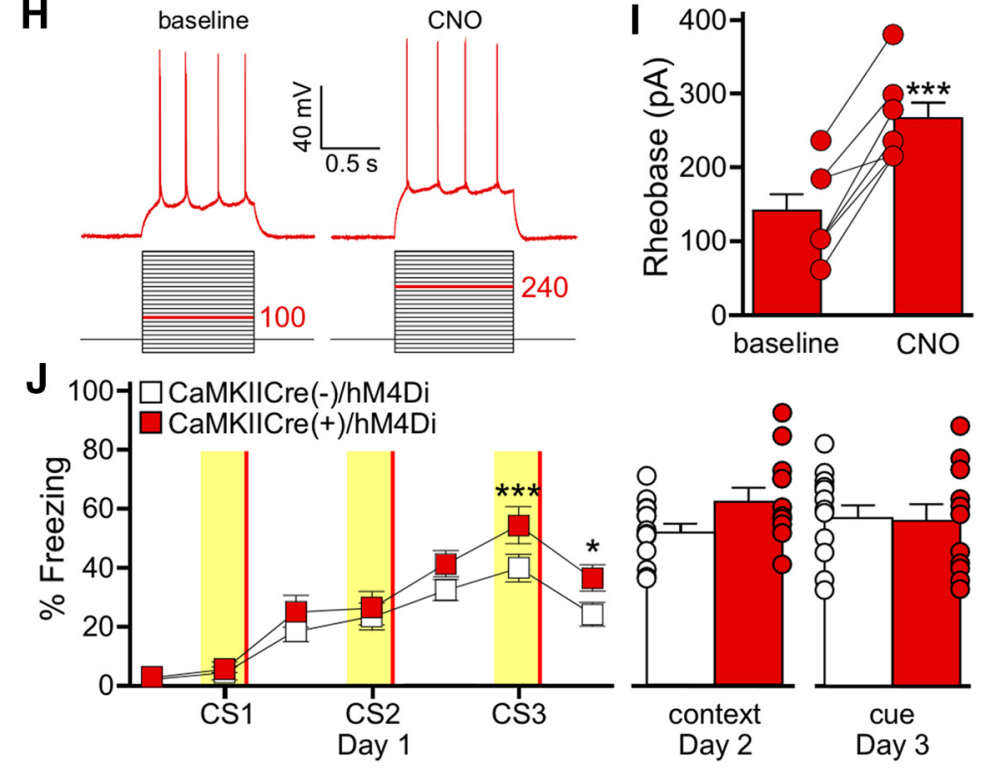

Figure 2. Chemogenetic inhibition of pyramidal neurons in the LA, but not BA impairs auditory fear conditioning. $\boldsymbol{A}$, hM4Di-mCherry fluorescence in the LA of a CaMKIICre(+) mouse, 4 weeks after infusion of AAV8-hSyn-DIO-hM4Di-mCherry. Scale bar, $50 \mu \mathrm{m}$. B, Schematic summarizing the distribution of hM4Di-mCherry fluorescence in the LA (spanning $-1.22 \mathrm{~mm}$ to $-1.94 \mathrm{~mm}$ posterior from 


\section{continued}

bregma) of CaMKIICre(+) mice evaluated in $\boldsymbol{E}$. $\boldsymbol{C}$, CNO-induced inhibition of an hM4Di-expressing LA pyramidal neuron. Rheobase was measured before (baseline) and after application of $\mathrm{CNO}(10 \mu \mathrm{M})$. The current-step protocol is depicted below the traces. The first step to elicit spiking is highlighted in red; the trace shown is the response to the denoted current step. $\boldsymbol{D}$, Rheobase summary for hM4Di-expressing LA pyramidal neurons, before and after CNO application $\left(t_{(3)}=4.4, * p=0.021\right)$. Each experiment is shown as connected circles $(n=4)$. $\boldsymbol{E}$, Impact of LA pyramidal neuron inhibition on auditory fear conditioning. CaMKIICre $(+) / \mathrm{hM} 4 \mathrm{Di}(\mathrm{black})$ and CaMKIICre(-)/hM4Di (white) mice were trained using a $3 \mathrm{CS} / 3$ US paradigm. CNO (2 mg/kg, i.p.) was administered 30 min before training. Freezing behavior during training is plotted on the left. The yellow bars represent CS presentations, and the red bars represent US presentations. There was no main effect of genotype $\left(F_{(1,54)}=2.6, p=0.14\right)$. The plots on the right show freezing during context $\left(t_{(9)}=4.0, * * p=0.003\right)$ and cue $\left(t_{(9)}=2.9, * p=0.017\right)$ recall tests. The bars represent the mean \pm SEM, with dots next to the bars denoting individual data points $(n=5-6$ /group). Sex differences were not assessed for this experiment. $\boldsymbol{F}$, hM4Di-mCherry fluorescence in the BA of a CaMKIICre(+) mouse, 4 weeks after infusion of AAV8-hSyn-DIO-hM4Di-mCherry. Scale bar, $50 \mu \mathrm{m}$. G, Schematic summarizing the distribution of hM4Di-mCherry fluorescence in the BA (coronal view, spanning $-1.22 \mathrm{~mm}$ to $-1.94 \mathrm{~mm}$ posterior from bregma) of CaMKIICre $(+) / \mathrm{hM} 4 \mathrm{Di}$ mice evaluated in $\boldsymbol{C}$. $\boldsymbol{H}$, CNO-induced inhibition of an hM4Di-expressing BA pyramidal neuron. Rheobase was measured before (baseline) and after application of CNO (10 $\mu$ M), as described for $\boldsymbol{C}$. I, Rheobase summary for hM4Di-expressing BA pyramidal neurons, before and after CNO application $\left(t_{(6)}=7.6\right.$, $\left.* * * p<0.001\right)$. Each experiment is shown as connected circles $(n=7)$. $\boldsymbol{J}$, Impact of BA pyramidal neuron inhibition on fear learning. CaMKIICre $(+) / \mathrm{hM} 4 \mathrm{Di}(\mathrm{red})$ and CaMKIICre (-)/hM4Di (white) mice were trained using a $3 \mathrm{CS} / 3$ US paradigm. CNO $(2 \mathrm{mg} / \mathrm{kg}$, i.p.) was administered $30 \mathrm{~min}$ before training. Freezing behavior during training is plotted on the left. The yellow bars represent CS presentations, and the red bars represent US presentations. There was a significant main effect of genotype $\left(F_{(1,132)}=4.9, p=0.038\right.$; CS3: $* * * p<0.001$, post-CS3: $* p=0.023)$. The plots on the right show freezing during context $\left(t_{(22)}=1.9, p=0.074\right)$ and cue $\left(t_{(29)}=0.1, p=0.905\right)$ tests. Error bars represent the mean \pm SEM, with dots next to the bars denoting individual data points $(n=5 / 6-7 / 5$ males/females per group).

and cue recall tests (Fig. 3D). Thus, GABA neuron activity in the $\mathrm{BA}$ is required for the acquisition of fear memory.

\section{Chemogenetic stimulation of BA GABA neurons promotes fear learning}

Previous work has shown that direct optogenetic stimulation of LA pyramidal neurons during presentation of a neutral auditory cue, in the absence of a footshock, is sufficient to generate a fear-like response to subsequent presentation of the cue (Johansen et al., 2010). Given the similar disruptive impact of chemogenetic inhibition of LA pyramidal (Fig. 2E) and BA GABA neurons (Fig. 3D) on fear learning, we next asked whether BA GABA neuron stimulation could also generate a learned response to an auditory cue. To test this, we injected a Cre-dependent excitatory chemogenetic virus (AAV8-hSyn-DIO-hM3DqmCherry) into the BA of GADCre(+) mice (Fig. 4A). As expected, the application of CNO increased the excitability (reduced the rheobase) of hM3Dq-expressing BA GABA neurons (Fig. 4B,C).

To assess the behavioral impact of this manipulation, we used a modified fear conditioning protocol in which subjects were given three presentations of an auditory cue/CS, without footshock/US (3 CS/O US; Tipps et al., 2014). BA GABA neuron stimulation during training yielded increased freezing to the third CS presentation (CS3), relative to controls (Fig. 4D). Significantly enhanced freezing was also seen in GADCre $(+) / h M 3 D q$ subjects during the subsequent context and cue recall tests, conducted in the absence of CNO (Fig. 4E,F). Importantly, no group differences in freezing behavior were observed before the first CS presentation during training (Fig. $4 C$ ), or in response to the altered context during the cue recall test (Fig. 4F). Further, GADCre(+)/hM3Dq mice froze significantly more during the CS presentations during the cue test compared to the non-CS periods, whereas GAD$\mathrm{Cre}(-) / \mathrm{hM} 3 \mathrm{Dq}$ subjects did not. These findings suggest that BA GABA neuron stimulation does not elicit a general increase in freezing behavior, but rather, promotes the formation of an associative response to an otherwise neutral auditory cue and associated context.

\section{Chemogenetic stimulation of BA GABA neurons inhibits BA pyramidal neurons}

Our data demonstrate that BA GABA neuron activity is necessary for fear memory acquisition (Fig. $3 D$ ) and sufficient to produce a long-term association between an auditory cue and associated context (Fig. 4D-F). GABA neurons in the BLA complex are thought to primarily be interneurons that regulate the activity of local pyramidal neurons (Woodruff and Sah, 2007; Spampanato et al., 2011; Veres et al., 2014, 2017; Vereczki et al., 2016). As such, the hM3Dq-mediated stimulation of BA GABA neurons should result in BA pyramidal neuron inhibition. To test this prediction, we measured mIPSCs in BA pyramidal neurons, before and after chemogenetic stimulation of BA GABA neurons. In slices from mice expressing hM3Dq in BA GABA neurons, bath application of CNO increased the frequency and amplitude of $\mathrm{GABA}_{A} \mathrm{R}$-mediated mIPSCs in BA pyramidal neurons (Fig. 5A-C). Additionally, BA pyramidal neuron excitability, as assessed by rheobase, was decreased by the hM3Dq-mediated stimulation of BA GABA neurons (Fig. 5D). Thus, BA GABA neuron stimulation increases inhibitory input to BA pyramidal neurons, and suppresses BA pyramidal neuron excitability.

\section{Chemogenetic inhibition of BA pyramidal neurons promotes fear learning}

Given that BA GABA neuron stimulation is sufficient to generate a long-term associative response to a neutral auditory cue, and that BA GABA neuron stimulation inhibits BA pyramidal neurons, we next asked whether the hM4Di-mediated inhibition of BA pyramidal neurons during training could also induce the formation of a long-term behavioral response to a neutral auditory cue. We again used CaMKIICre(+) mice and an AAV8-hSyn-DIO-hM4Di- 
A

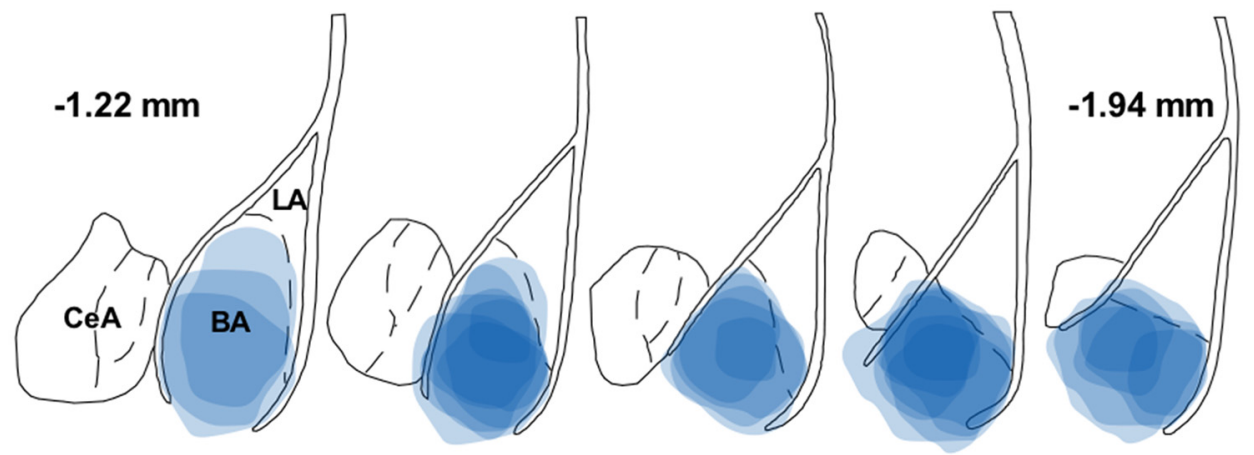

B
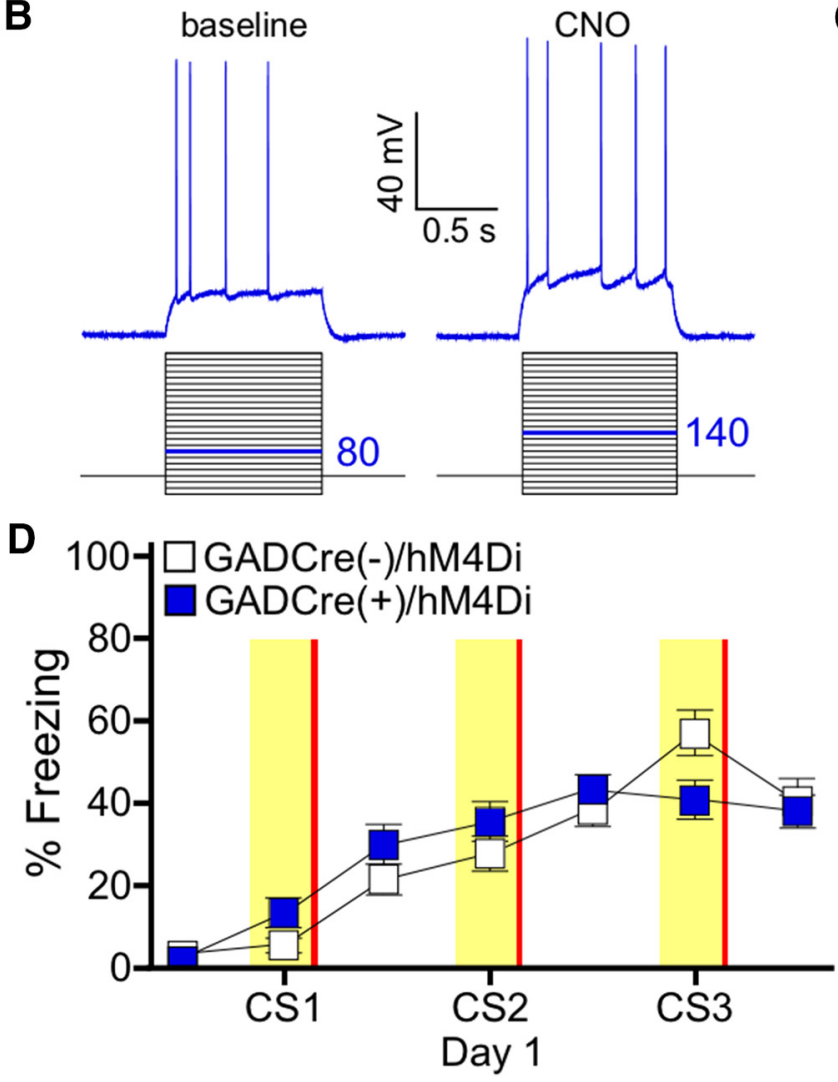
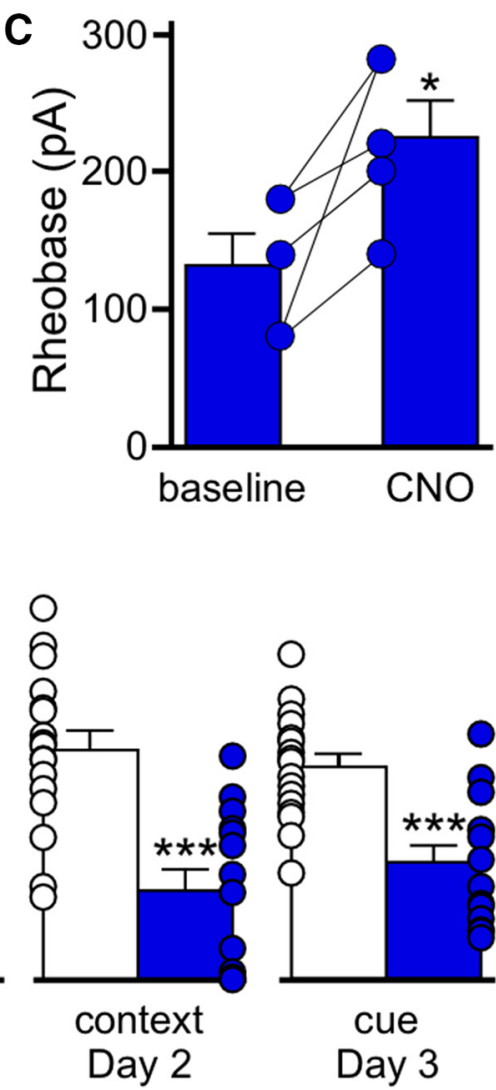

Figure 3. Chemogenetic inhibition of BA GABA neurons impairs auditory fear conditioning. $\boldsymbol{A}$, Schematic summarizing the distribution of hM4Di-mCherry fluorescence in the BA (coronal view, spanning $-1.22 \mathrm{~mm}$ to $-1.94 \mathrm{~mm}$ posterior from bregma) of GADCre $(+) / \mathrm{hM} 4 \mathrm{Di}$ mice evaluated in $\boldsymbol{D}$. $\boldsymbol{B}, \mathrm{CNO}$-induced inhibition of an hM4Di-expressing BA GABA neuron. Rheobase was measured before (baseline) and after application of CNO $(10 \mu \mathrm{m})$. The current-step protocol is depicted below the traces. The first step to elicit spiking is highlighted in blue; the trace shown is the response to the denoted current step. $\boldsymbol{C}$, Rheobase summary for hM4Di-expressing BA GABA neurons, before and after CNO application $\left(t_{(4)}=3.2, * p=0.033\right)$. Each experiment is shown as connected circles $(n=5)$. $\boldsymbol{D}$, Impact of BA GABA neuron inhibition on fear learning. GADCre(+)/hM4Di (blue) and GADCre(-)/hM4Di (white) mice were trained with a $3 \mathrm{CS} / 3$ US paradigm. CNO (2 mg/kg, i.p.) was given $30 \mathrm{~min}$ before training. Freezing during training is shown on the left. The yellow bars denote CS presentations and the red bars indicate US presentations. There was no main effect of genotype $\left(F_{(1,174)}=0.1, p=\right.$ $0.71)$. The plots on the right show freezing during context $\left(t_{(29)}=4.9, * * * p<0.001\right)$ and cue $\left(t_{(29)}=4.5\right.$, $\left.* * * p<0.001\right)$ tests. Error bars represent the mean \pm SEM, with dots next to the bars denoting individual data points $(n=6 / 8-9 / 8$ males/females group).

mCherry virus to express hM4Di in BA pyramidal neurons (Fig. 6A), and administered CNO to viral-treated CaMKIICre $(+)$ and CaMKIICre $(-)$ subjects 30 min before training in the $3 \mathrm{CS} / 0$ US paradigm. Similar to the outcome of the BA GABA neuron stimulation experiments, BA pyramidal neuron inhibition promoted freezing to the second and third CS presentations during training, but had no effect on freezing before the first CS presentation (Fig. 6B).
Moreover, BA pyramidal neuron inhibition during training resulted in the formation of a long-term associative response, as revealed by increased freezing relative to control subjects in both the context and cue recall tests (Fig. $6 C, D)$. Importantly, no group differences were observed on initial introduction of the subjects to the altered context during the cue test (Fig. 6D). Further, CaMKIICre $(+) /$ hM4Di mice, but not CaMKIICre(-)/hM4Di mice, froze 
A
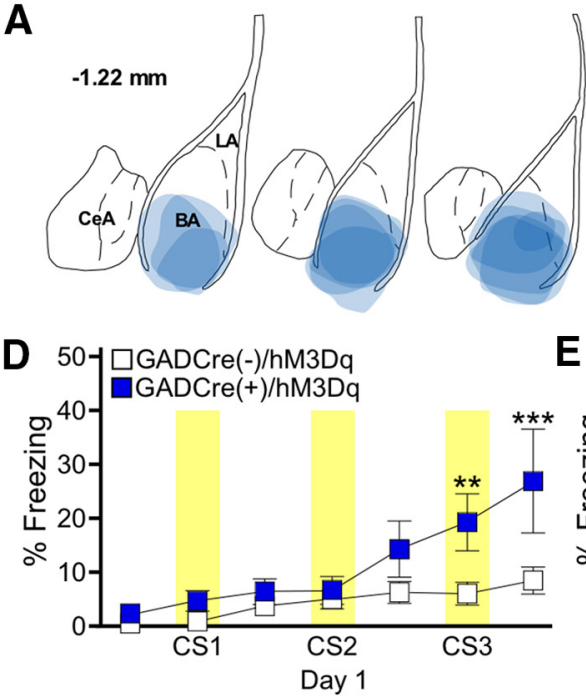

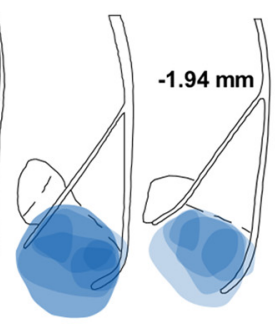

E $50-$

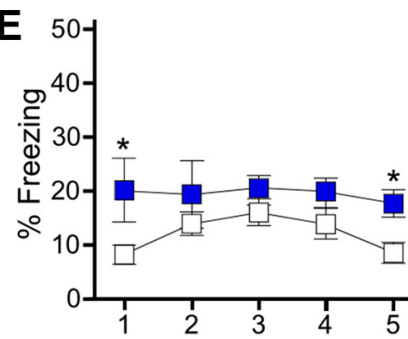

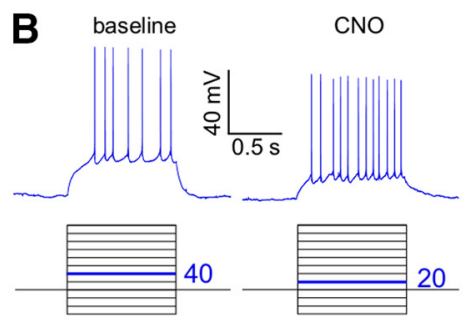

F

F $50-$
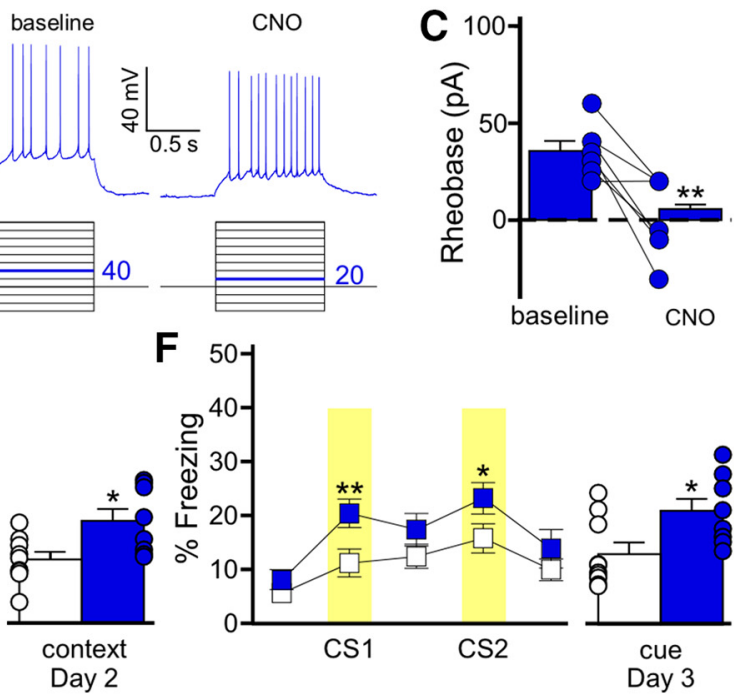

Figure 4. BA GABA neuron stimulation generates an association between a behavior and an auditory cue. $\boldsymbol{A}$, Schematic summarizing the distribution of hM3Dq-mCherry fluorescence in the BA (coronal view, spanning $-1.22 \mathrm{~mm}$ to $-1.94 \mathrm{~mm}$ posterior from bregma) of the GADCre $(+) / \mathrm{hM} 3 \mathrm{Dq}$ mice evaluated in $\boldsymbol{D}-\boldsymbol{F}$. $\boldsymbol{B}$, CNO-induced stimulation of an hM3Dq-expressing BA GABA neuron. Rheobase was measured before (baseline) and after application of CNO $(10 \mu \mathrm{M})$. The current-step protocol is depicted below the traces. The first step to elicit spiking is highlighted in blue; the trace shown is the response to the denoted current step. $\boldsymbol{C}$, Rheobase summary for hM3Dq-expressing BA GABA neurons, before and after CNO application $\left(t_{(6)}=4.4, * * p<0.001\right)$. Each experiment is represented as connected circles $(n=7)$. $\boldsymbol{D}$, Impact of BA GABA neuron stimulation during training. Freezing behavior during training (3 CS/0 US) for GADCre $(+) / \mathrm{hM} 3 \mathrm{Dq}$ (blue) and GADCre $(-) / \mathrm{hM} 3 \mathrm{Dq}$ (white) mice. CNO (2 mg/kg, i.p.) was given 30 min before training. Yellow bars represent CS presentations. There was a significant main effect of genotype $\left(F_{(1,90)}=6.5, p=0.020 ;\right.$ CS3: $* * p=0.005$, post-CS3: $* * * p<0.001)$. $E$, Freezing during the context recall test. The plot on the left shows freezing for each 1 min bin of the 5 min context test. There was a significant main effect of genotype $\left(F_{(1,60)}=7.9, p=0.013\right.$; bin $1: * p=0.01$, bin 5 : $\left.* p=0.04\right)$. The plot on the right shows the mean percentage freezing for the entire context test $\left(t_{(15)}=-2.8, * p=0.013\right)$. $\boldsymbol{F}$, Freezing during the cue recall test. The plot on the right shows freezing during each $3 \mathrm{~min}$ bin of the cue test, with CS presentations highlighted in yellow. There was a significant main effect of genotype $\left(F_{(1,75)}=13.6, p<0.001\right.$; CS1: $* * p=0.008$, CS2: $\left.* p=0.03\right)$. GADCre $(+) / \mathrm{hM} 3 \mathrm{Dq}\left(t_{(14)}=-2.6, \mathrm{p}\right.$ $=0.021)$, but not GADCre $(-) / \mathrm{hM} 3 \mathrm{Dq}$ mice $\left(t_{(16)}=-1.5, p=0.152\right)$ froze significantly more during the CS periods than the non-CS periods. The bars on the right represent mean percentage freezing during the combined CS presentations $\left(t_{(15)}=-2.5, * p=0.023\right)$. Error bars in $\boldsymbol{C}, \boldsymbol{E}$, and $\boldsymbol{F}$ represent the mean \pm SEM, with dots next to the bars denoting individual data points $(n=4 / 4-5 / 4$ males/females per group).

significantly more during the CS presentations during the cue test compared to the non-CS periods. These findings suggest that chemogenetic inhibition of BA pyramidal neurons does not elicit a general increase in freezing behavior, but rather, supports the formation of an associative response to an otherwise neutral auditory cue and associated context.

Although these data suggest that BA pyramidal neuron inhibition is a key contributor to associative memory formation, we designed a series of control experiments to test alternative explanations. First, although our study design ensured that all animals received the same viral construct and CNO treatment, a baseline difference in fear learning between $\mathrm{CaMKIICre}(-)$ and $\mathrm{CaMKIICre(+)}$ littermates could explain our observations. There was no difference in freezing behavior, however, during training or recall tests for untreated $\mathrm{CaMKIICre}(+)$ and $\mathrm{CaMKIICre}(-)$ littermates trained with the $3 \mathrm{CS} / 0$ US protocol, in the absence of CNO (Fig. 7A). Second, although freezing levels were similar across groups before the initial CS presentation during training, and on initial exposure to the altered context during the cue test, we conducted additional tests to determine if chemogenetic inhibition of BA pyramidal neurons resulted in locomotor impairments and/or nonspecific freezing behavior. Chemogenetic inhibition of BA pyramidal neurons had no impact on freezing behavior or the average motion index or maximum motion measures during training using a $0 \mathrm{CS} / 0$ US paradigm (context exposure only; Fig. 7B). Freezing behavior in the subsequent recall tests was also unaffected (Fig. 7B). In addition to demonstrating that chemogenetic inhibition of BA pyramidal neurons does not evoke a nonspecific increase in freezing behavior (or a nonspecific decrease in locomotion), these data also show that the learned association generated by BA pyramidal neuron inhibition requires a discrete CS presentation.

The dependence of the CNO/hM4Di-induced fear memory on CS presentation raised the possibility that BA pyramidal neuron inhibition during training may simply strengthen an otherwise weak association between the US and auditory CS. To test this prospect, we used a weak conditioning protocol involving a single CS-US pairing (1 CS/1 US), which would allow us to detect an increase in freezing behavior that might be obscured in more robust standard (3 CS/3 US) conditioning protocol. BA pyramidal neuron inhibition during conditioning in the $1 \mathrm{CS} / 1$ US protocol did not alter freezing during training or enhance context or cue-induced freezing in recall tests 
A

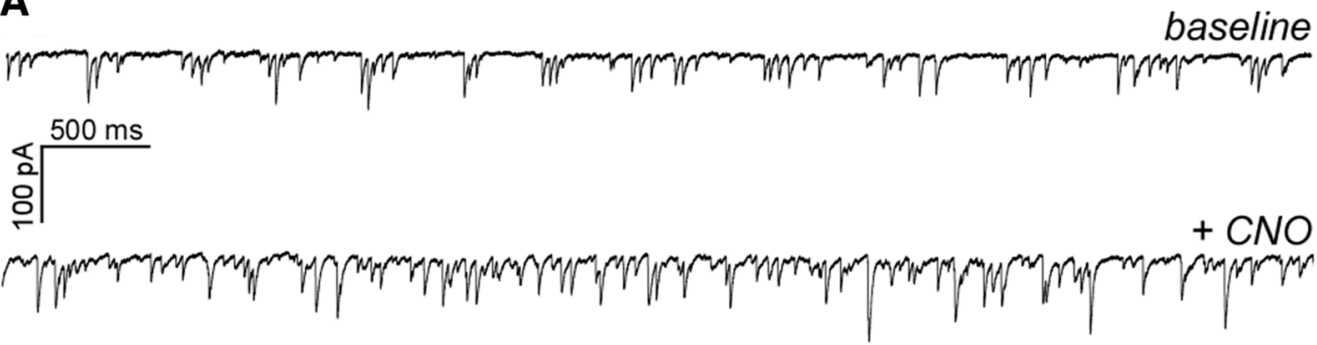

$+P T X$
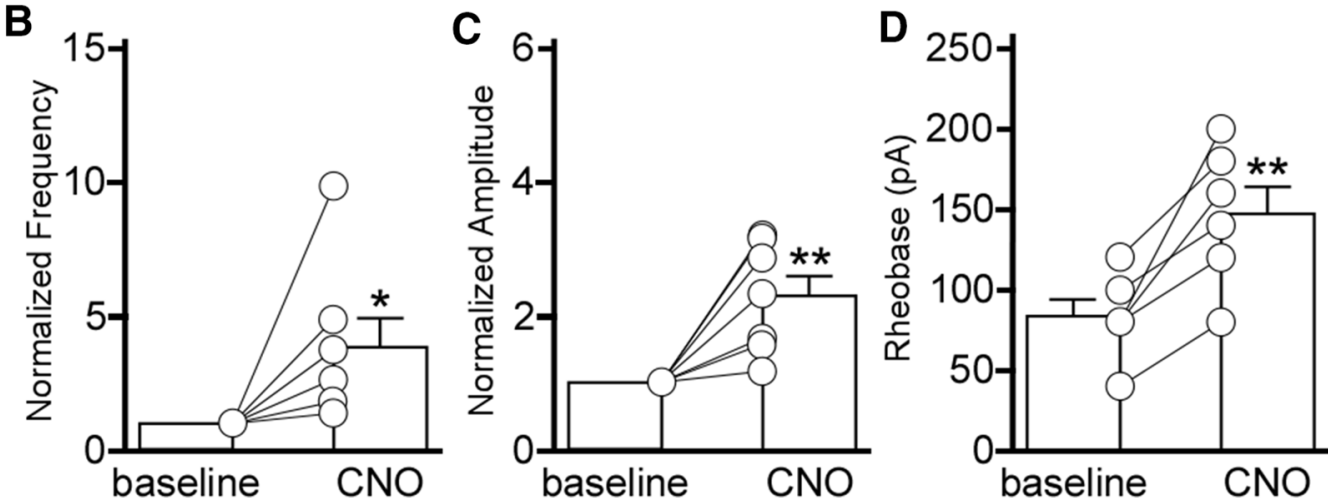

Figure 5. BA GABA neuron stimulation inhibits BA pyramidal neurons. $\boldsymbol{A}$, mIPSCs in BA pyramidal neurons from GADCre(+)/hM3Dq mice $\left(V_{\text {hold }}=-70 \mathrm{mV}\right)$. Traces show mIPSCs before (baseline) and after application of CNO (10 $\left.\mu \mathrm{m}\right)$, and mIPSC sensitivity to the GABA $_{A} R$ antagonist PTX $(100 \mu \mathrm{M})$. B, Impact of CNO/hM3Dq-mediated activation of BA GABA neurons on mIPSC frequency in BA pyramidal neurons $\left(t_{(6)}=2.6, * p=0.400\right)$. Post-CNO measures were normalized to baseline for each recording because of significant cell-to-cell variability in mIPSC activity ( $n=7$ experiments). $\boldsymbol{C}$, Impact of CNO/hM3Dq-mediated activation of BA GABA neurons on mIPSC amplitude in BA pyramidal neurons $\left(t_{(6)}=4.1, * * p=0.006\right)$; post-CNO measures were normalized to baseline values for each recording ( $n=7$ experiments). $\boldsymbol{D}$, Impact of CNO/hM3Dq-mediated activation of BA GABA neurons on rheobase in BA pyramidal neurons, at baseline and after CNO application $\left(t_{(5)}=4.8, * * p=0.005 ; n=6\right.$ experiments).

(Fig. 7C). Thus, although BA pyramidal neuron inhibition may induce memory formation, it does not determine the strength of the association when a US is presented.

Finally, as anxiety can impact performance in fear conditioning tests (Izquierdo et al., 2016), we asked whether BA pyramidal neuron inhibition altered anxiety-related behavior, using the EPM test. BA pyramidal neuron inhibition did not alter time spent in the open arms of the EPM or number of total (open + closed) arm entries (Fig. 7D), indicating that BA pyramidal neuron inhibition does not impact anxiety-related behavior or general motor activity. Collectively, these data also suggest that inhibition of BA pyramidal neurons does not promote a subjective sense of fear, which would be expected to generate increased freezing in both the $0 \mathrm{CS} / 0$ US and $1 \mathrm{CS} / 1$ US conditions, and potentially decrease the time spent in the open arms of the EPM.

\section{Chemogenetic induction of fear learning requires GIRK channel activation in BA pyramidal neurons}

Chemogenetic tools regulate neuronal excitability by using endogenous $\mathrm{G}$ protein-dependent signal transduction pathways. For example, hM4Di is thought to inhibit neurons by activating inhibitory $\left(\mathrm{G}_{\mathrm{i} / \mathrm{o}}\right)$ G-proteins (Armbruster et al., 2007). G-protein-gated inwardly rectifying
$\mathrm{K}^{+}$(GIRK) channels mediate $\mathrm{G}_{\mathrm{i} / \mathrm{o}}$-dependent signaling in many neuron populations (Lüscher and Slesinger, 2010; Lüjan et al., 2014), including BA pyramidal neurons (Marron Fernandez de Velasco et al., 2017), and they have been implicated in the inhibitory effect of hM4Di (Armbruster et al., 2007). Thus, as a final test for the specificity of our chemogenetic manipulation on associative learning, we asked whether the hM4Di-dependent inhibition of BA pyramidal neurons could be blocked by GIRK channel ablation.

We used a neuron-specific Girk $1^{-/-}$mouse line [CaMKIICre(+):Girk $1^{\text {fl/fI }}$ mice] that lacks GIRK channel activity in pyramidal neurons in multiple brain regions, including the BA (Marron Fernandez de Velasco et al., 2017). In hM4Diexpressing BA pyramidal neurons from CaMKIICre $(+)$ (control/Girk ${ }^{+/+}$) mice, CNO evoked an outward/inhibitory current that was reversed by $0.3 \mathrm{~mm}$ extracellular $\mathrm{Ba}^{2+}$, which blocks inwardly rectifying channels, including GIRK channels (Fig. 8A). In hM4Di-expressing BA pyramidal neurons from CaMKIICre $(+)$ :Girk $1^{f l f f l}$ mice, CNO-induced currents were significantly smaller (Fig. $8 A, B$ ), and the inhibitory influence of CNO on BA pyramidal neuron excitability (shown as change in rheobase) was blunted (Fig. $8 C)$. Thus, GIRK channel activation mediates most of the 

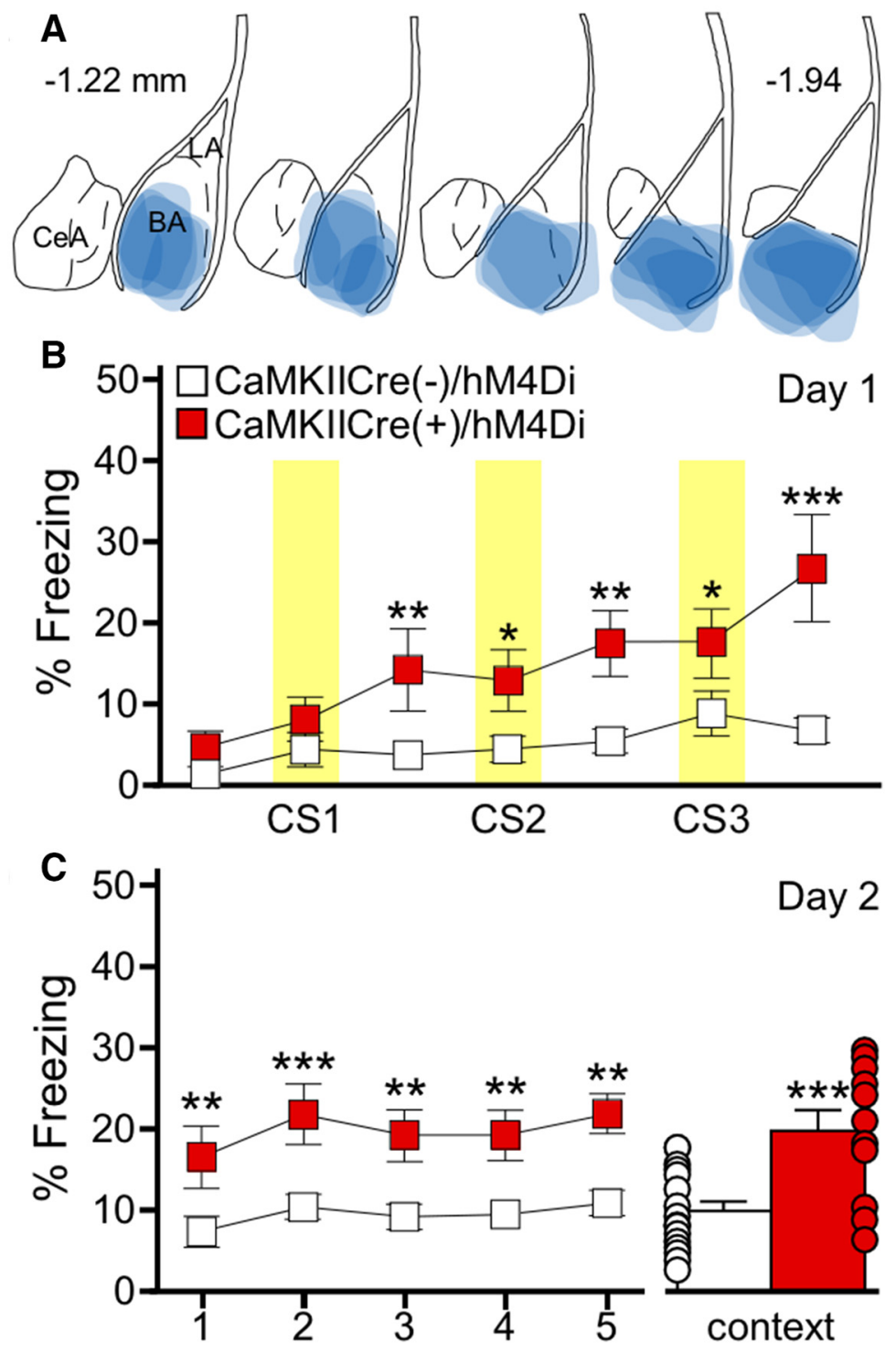

Day 2

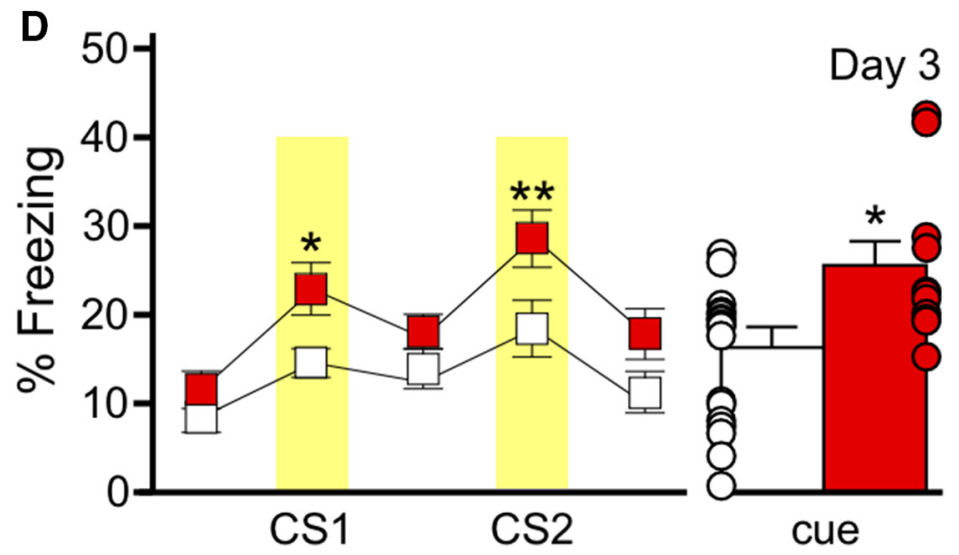

Figure 6. BA pyramidal neuron inhibition generates an association between a behavior and an auditory cue. $\boldsymbol{A}$, Schematic summarizing the distribution of hM4Di-mCherry fluorescence in the BA (coronal view, spanning $-1.22 \mathrm{~mm}$ to $-1.94 \mathrm{~mm}$ posterior from bregma) of the CaMKIICre $(+) / \mathrm{hM} 4 \mathrm{Di}$ mice evaluated in $\boldsymbol{B}-\boldsymbol{D}$. B , Training with the $3 \mathrm{CS} / 0$ US protocol in CaMKIICre $(+) / \mathrm{hM} 4 \mathrm{Di}(\mathrm{red})$ and CaMKIICre $(-) / \mathrm{hM} 4 \mathrm{Di}$ (white) mice. CNO (2 mg/kg, i.p.) was given $30 \mathrm{~min}$ before training. Yellow bars represent the CS presentations. There was a significant main effect of genotype $\left(F_{(1,162)}=14.1, p<0.001\right.$; post-CS1: $* * p=0.006$, CS2: $* p=0.025$, post-CS2: $* * p=0.002$, CS3: $* p=0.019$, post-CS3: $* * * p<0.001)$. $\boldsymbol{C}$, Freezing during the context recall test. The plot on the left shows freezing during each $1 \mathrm{~min}$ bin of the 5 min test. There was main effect of genotype $\left(F_{(1,104)}=16.1, p<0.001 ;\right.$ bin $1: * * p=$ 


\section{continued}

0.007 , bin 2: $* * * p<0.001$, bin 3: $* * p=0.004$, bin 4: $* * p=0.004$, bin 5: $* * p=0.001)$. Error bars on the right show mean percentage freezing for the full 5 min context test $\left(t_{(29)}=-4.2\right.$, ***p $\left.<0.001\right)$. $\boldsymbol{D}$, Freezing during the cue recall test. The plot on the left shows freezing during each 3 min portion of the test, with yellow bars representing the CS presentations. There was a significant effect of genotype $\left(F_{(1,108)}=5.2, p=0.03\right.$; CS1: $* p=0.02$, CS2: $\left.* * p=0.005\right)$. CaMKIICre $(+) / \mathrm{hM} 4 \mathrm{Di}$ mice $\left(t_{(24)}=-3.3, p=0.004\right)$, but not CaMKIICre $(-) / \mathrm{hM} 4 \mathrm{Di}$ mice $\left(t_{(34)}=-1.8, p=0.080\right)$ froze significantly more during the CS presentations compared to the non-CS periods. The bars on the right show mean percentage freezing during the combined CS presentations $\left(t_{(29)}=-2.2, * p=0.039\right)$. Error bars in $\boldsymbol{B}-\boldsymbol{D}$ represent the mean \pm SEM, with dots next to each bar denoting the individual data points $(n=6 / 7-10 / 8$ males/females per group).

inhibitory effect of hM4Di activation on BA pyramidal neurons.

To test whether GIRK channel activation is also required for the chemogenetic induction of associative learning, we evaluated CaMKIICre(+):Girk $1^{\text {fl/fl }}$ mice in the $3 \mathrm{CS} / 0$ US conditioning protocol, 4 weeks after intra-BA infusion of AAV8-hSyn-DIO-hM4Di-mCherry virus. Mice were randomly assigned to receive saline or CNO $30 \mathrm{~min}$ before training. The levels of freezing observed during training, and in subsequent context and cue recall tests, did not differ between saline- and CNO-treated subjects (Fig. $8 D$ ). Thus, the loss of GIRK channels, a primary mediator of hM4Di influence in BA pyramidal neurons, is sufficient to block the generation of an associative behavioral response via chemogenetic inhibition of BA pyramidal neurons.

\section{Discussion}

Inhibitory interneurons regulate the activity of local excitatory principal neurons in many brain regions. These interneurons are critical for shaping network activity and exhibit experience-induced plasticity, suggesting that changes in inhibitory signaling may underlie long-term learning and behavioral changes (Lucas and Clem, 2018). Within the field of learning and memory, the impact of inhibitory interneuron activity is well illustrated by the
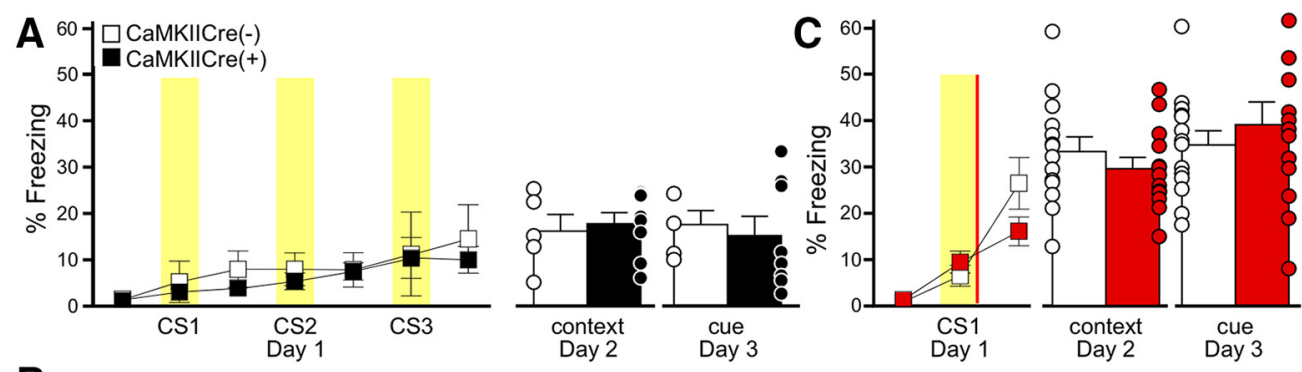

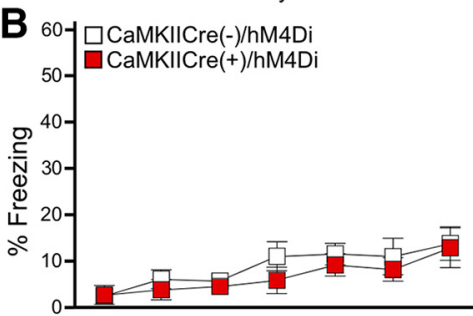

Day 1
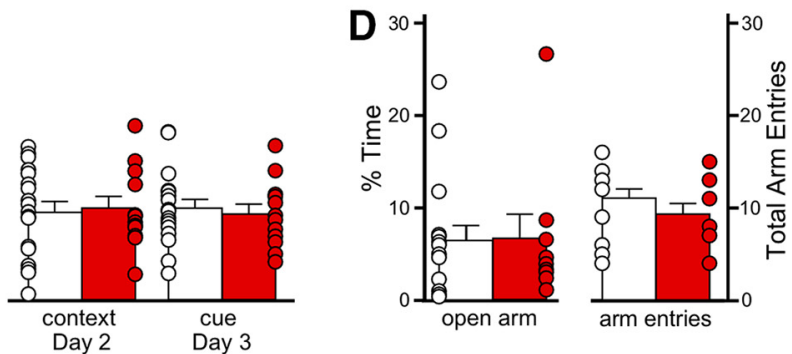

Figure 7. Induction of memory formation by BA pyramidal neuron inhibition is not because of genotype differences, nonspecific freezing behavior, or anxiety changes. $\boldsymbol{A}$, Genotype difference test. Training with the $3 \mathrm{CS} / 0$ US protocol in untreated CaMKIICre(+) (black) and CaMKIICre(-) (white) mice is shown on the left. Yellow bars represent the CS presentations. There was no effect of genotype $\left(F_{(1,66)}=0.37, p=0.55\right)$. Freezing during context $\left(t_{(11)}=-0.4, p=0.73\right)$ and cue $\left(t_{(11)}=0.4, p=0.69\right)$ recall tests for untreated CaMKIICre $(+)$ and CaMKIICre $(-)$ littermates, following conditioning with the $3 \mathrm{CS} / 0$ US protocol, is plotted on the right. Sex effects were not analyzed for this study ( $n=5-8 /$ genotype). $\boldsymbol{B}$, Nonspecific freezing behavior test. Training with the $0 \mathrm{CS} / 0 \mathrm{US}$ protocol in $\mathrm{CaMKIICre}(+) / \mathrm{hM} 4 \mathrm{Di}(\mathrm{red})$ and CaMKIICre(-)/hM4Di (white) mice is shown on the left. CNO (2 mg/kg, i.p.) was given $30 \mathrm{~min}$ before training. No CS or US presentations were given. The plot on the left show freezing during training. No genotype differences were seen during training $\left(F_{(1,168)}=0.5, p=0.49\right)$. The plots on the right show freezing during context $\left(t_{(28)}=-0.0, p=0.98\right)$ and cue $\left(t_{(28)}=-0.5\right.$, $p=0.65)$ recall tests $\left(n=6 / 6-8 / 10\right.$ males/females per group). No genotype differences were detected in average motion $\left(F_{(1,140)}=0.9\right.$, $p=0.35$ ) or maximum motion $\left(F_{(1,140)}=0.95, p=0.34\right)$ indices (data not shown). $\boldsymbol{C}$, One CS/US protocol test. Freezing following training with a weak (1 CS/1 US) fear conditioning protocol in CaMKIICre $(+) / \mathrm{hM} 4 \mathrm{Di}$ (red) and CaMKIICre $(-) / \mathrm{hM} 4 \mathrm{Di}$ (white) mice is shown on the left. CNO (2 mg/kg, i.p.) was given $30 \mathrm{~min}$ before training. The yellow bar represents the CS presentation and the red bar represents the US presentation. There was no effect of genotype $\left(F_{(1,50)}=0.83, p=0.37\right)$. The plots on the right show freezing during context $\left(t_{(25)}=1.0, p=0.35\right)$ and cue $\left(t_{(25)}=-0.8, p=0.46\right)$ recall tests $(n=7 / 6-7 / 7$ males/females per group). $\boldsymbol{D}$, Anxiety test. Percentage of time spent in the open arms $\left(\boldsymbol{D} ; t_{(23)}=0.1, p=0.94\right)$ by CaMKIICre $(+) / \mathrm{hM} 4 \mathrm{Di}(\mathrm{red})$ and CaMKIICre $(-) / \mathrm{hM} 4 \mathrm{Di}($ white $)$ mice and total number of arm entries $\left(E ; t_{(23)}=1.1, p=0.28\right)$. All subjects received CNO $(2 \mathrm{mg} / \mathrm{kg}$, i.p.) $30 \mathrm{~min}$ before EPM testing $(n$ $=5 / 5-8 / 7$ males/females group). Bars represent the mean \pm SEM, with dots next to each bar denoting the individual data points. 

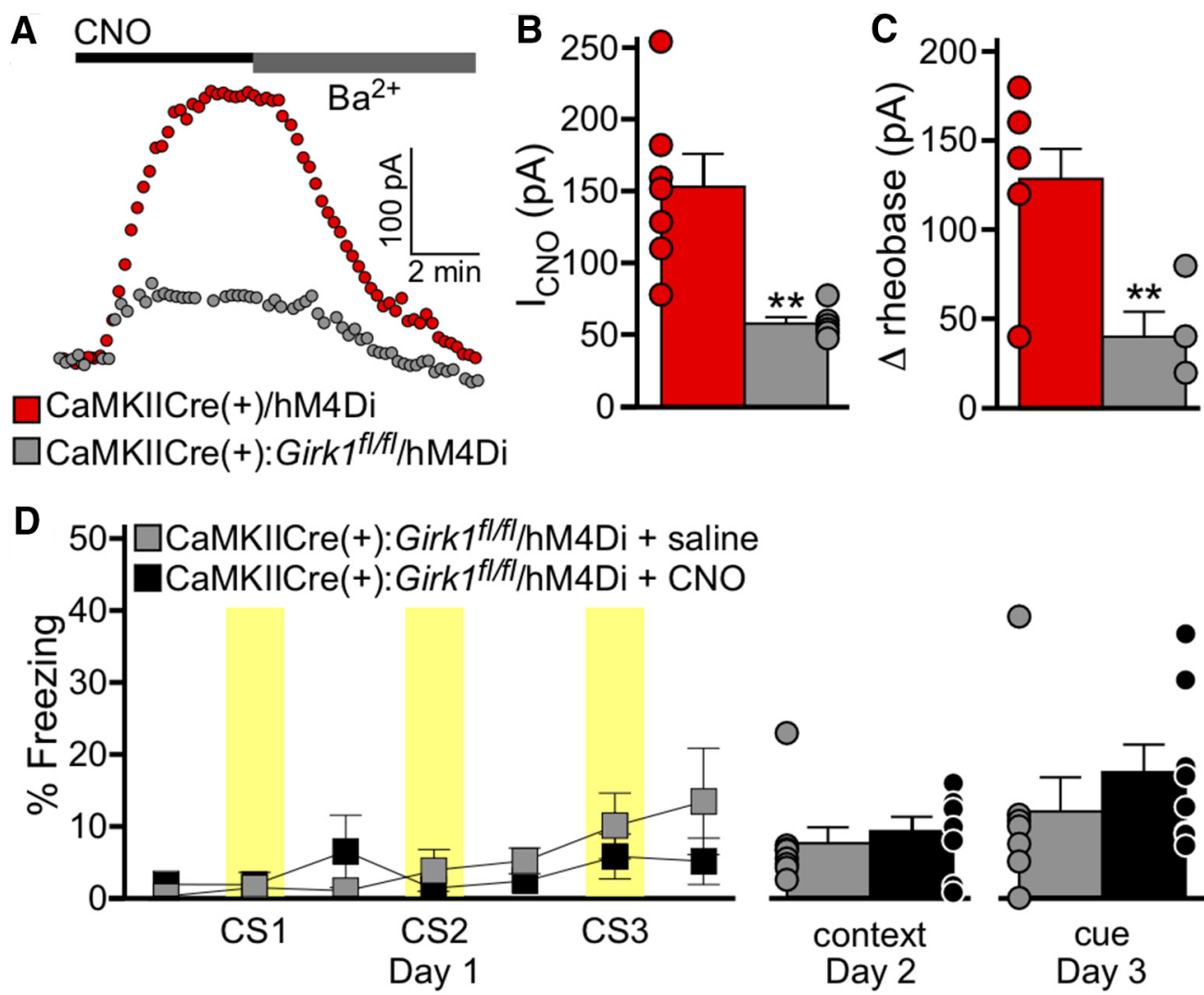

Figure 8. Chemogenetic induction of associative learning requires GIRK channel activation. $\boldsymbol{A}$, Currents evoked by $\mathrm{CNO}$ (10 $\mu \mathrm{M})$ in BA pyramidal neurons from CaMKIICre(+)/hM4Di (Girk $1^{+/+}$; red) and CaMKIICre(+):Girk $1^{f l / f l} / \mathrm{hM} 4 \mathrm{Di}\left(\right.$ Girk $1^{-/-}$; gray) mice. Currents were reversed by bath application of $0.3 \mathrm{~mm} \mathrm{Ba}^{2+}$. $\boldsymbol{B}$, Summary of CNO-induced currents in hM4Di-positive BA pyramidal neurons from CaMKIICre $(+) / \mathrm{hM} 4 \mathrm{Di}$ (Girk $1^{+/+}$; red) and CaMKIICre $(+)$:Girk $1^{f / f l} / \mathrm{hM} 4 \mathrm{Di}\left(\right.$ Girk $1^{-/-}$; gray) mice $\left(t_{(11)}=3.9, * * p=0.003 ; n=\right.$ $6-7 /$ group). $\boldsymbol{C}$, CNO-induced change in rheobase ( $\Delta$ rheobase) in hM4Di-positive BA pyramidal neurons from CaMKIICre $(+) / \mathrm{hM} 4 \mathrm{Di}$ $\left(\right.$ Girk $1^{+/+}$; red) and CaMKIICre(+):Girk $1^{f l / f l} / \mathrm{hM} 4 \mathrm{Di}\left(\right.$ Girk $1^{-/-} ;$gray) mice $\left(t_{(9)}=3.6, * * p=0.006 ; n=6-7 /\right.$ group). $\boldsymbol{D}$, Saline (gray) or CNO (2 mg/kg, i.p.; black) was administered to CaMKIICre(+):Girk $1^{f / f l} / \mathrm{hM} 4 \mathrm{Di}$ mice, $30 \mathrm{~min}$ before training in the $3 \mathrm{CS} / 0$ US protocol. Freezing during training is plotted on the left. Yellow bars represent the CS presentations. There was no effect of genotype $\left(F_{(1,84)}=0.3, p=0.58\right)$. Freezing during context $\left(t_{(14)}=0.6, p=0.57\right)$ and cue $\left(t_{(13)}=0.9, p=0.38\right)$ recall tests is plotted on the right ( $n=8 \mathrm{mice} / \mathrm{group})$. Bars represent the mean $\pm \mathrm{SEM}$, with dots next to each bar denoting the individual data points. Sex effects were not analyzed for this study.

disinhibition model of associative fear memory formation (Letzkus et al., 2015). In this model, the combined effect of exposure to a CS and US during training results in an overall decrease in GABAergic input to glutamatergic projection neurons, leading to an increase in projection neuron excitability. Examples of disinhibition-based signaling can be found in several brain regions, including the cortex (Letzkus et al., 2011) and BLA complex (Wolff et al., 2014).

Available data support the contention that excitation of LA pyramidal neurons is a critical step in auditory fear conditioning. For example, optogenetic stimulation of LA pyramidal neurons in mice can generate or enhance fear memory formation (Johansen et al., 2010; Yiu et al., 2014), whereas optogenetic (Johansen et al., 2014) or chemogenetic (Fig. 2) inhibition of LA pyramidal neurons impairs fear learning. In addition, the excitability of LA pyramidal neurons correlates positively with inclusion of those neurons in the subsequent fear memory trace (Zhou et al., 2009; Kim et al., 2014). Consistent with a key role for pyramidal neuron excitation in fear memory formation, the combined effect of exposure to a CS and US during fear conditioning results in an overall decrease in GABAergic input to pyramidal neurons of the BLA complex, resulting in pyramidal neuron disinhibition (Wolff et al., 2014). Indeed, manipulations of the parvalbumin-expressing subtype of GABA neurons in the BLA complex have been shown to modulate the strength of associative memory formation in response to a footshock, with inhibition of parvalbumin-expressing neurons during the CS-US presentation increasing fear learning and stimulation of parvalbumin-expressing neurons impairing fear learning (Wolff et al., 2014).

While studies have consistently illustrated the role of LA pyramidal neuron excitation in auditory fear conditioning, most of the published lesion and pharmacological inhibition studies have not supported a role for the BA in the acquisition of cue fear memories (Nader et al., 2001; Anglada-Figueroa and Quirk, 2005; Calandreau et al., 2005; Onishi and Xavier, 2010; Akagi Jordão et al., 2015). However, given that lesions and pharmacologic inhibitors lack neuronal specificity and can have broad and nonspecific effects on neural circuits, we revisited the role of the 
BA in auditory fear learning using a neuron-specific chemogenetic approach. We found that activation of $B A$ GABA neurons and inhibition of BA pyramidal neurons are critical steps in the formation of associative fear memories. Given that optogenetic stimulation of LA principal neurons (Johansen et al., 2014), and chemogenetic inhibition of BA pyramidal neurons (Fig. 6), can both promote the formation of learned response to a neutral auditory cue, our data suggest the intriguing prospect that the fear conditioning-induced disinhibition of LA pyramidal neurons triggers the stimulation of BA GABA neurons and feedforward inhibition of BA pyramidal neurons.

This conceptual framework can reconcile apparently contradictory prior observations related to the impact of lesions, as well as pharmacologic and genetic interventions, on auditory fear conditioning. For example, the lack of impact of pharmacological inactivation of the BA during auditory fear conditioning was interpreted as evidence that the BA is not required for fear learning (Calandreau et al., 2005). Given that chemogenetic inhibition of BA pyramidal neurons also did not preclude fear learning (Fig. 2), we speculate that the potentially detrimental effect on fear learning of inhibiting BA GABA neurons using a broad pharmacological approach might be offset by the direct inhibition of BA pyramidal neurons. Similarly, a system in which LA pyramidal neuron inhibition significantly impairs long-term memory formation, whereas BA pyramidal neuron inhibition does not, could explain why some manipulations of pyramidal neurons across the entire BLA complex during training resulted in significant impairments observed during recall testing (Wolff et al., 2014), whereas others did not (Namburi et al., 2015). Our results show that inhibitory manipulations of pyramidal neurons within the BLA complex that bias toward the LA would be expected to impair fear memory formation, whereas the same manipulation primarily targeted within the BA would not. A more extensive analysis of these manipulations in the LA will be needed to confirm this hypothesis, however. The work presented here focuses on the BA, primarily based on our initial finding that pyramidal inhibition in the LA produced the anticipated impairment in fear memory formation, whereas BA pyramidal neuron inhibition did not. Although our investigation of this interesting distinction yielded novel results, the application of our approach to the LA may also yield surprising effects, and will be an important direction for future work.

Our data suggest an interesting extension of the circuitry and signaling mechanisms implicated in auditory fear learning; however, limitations associated with the approaches used in this study are worth noting. First, although the CaMKIICre and GADCre transgenic mouse lines used in this study facilitated the manipulation of distinct neuron populations, pyramidal and GABA neurons in the BLA complex are diverse. The GADCre line, for example, drives expression in all major GABA neuron subtypes (Taniguchi et al., 2011), including the PV and somatostatin subtypes that exert opposing influence on LA pyramidal neuron activity (Lovett-Barron et al., 2014; Wolff et al., 2014; Lucas and Clem, 2018). Thus, extending our efforts to identify the relevant subpopulation(s) of inhibitory interneurons that are essential for auditory fear conditioning will be informative. Similarly, the afferent and efferent connections of pyramidal neurons in the BLA complex are diverse, and these distinctions have significant implications for both conditioned fear and anxiety (Janak and Tye, 2015; Beyeler et al., 2016, 2018; BurgosRobles et al., 2017). Thus, it will be interesting to use projection-specific chemogenetic manipulations of discrete BA microcircuits to understand which projection(s) is/are most relevant to the facilitation of associative learning by inhibitory signaling reported in this study.

We also note that the time course of the chemogenetic manipulations used in this study encompassed most of the acquisition and consolidation periods (Roth, 2016). Although this design allowed us to probe the role of inhibitory signaling without an a priori assumption regarding when such signaling might be relevant, future work using a more temporally discrete approach will be needed to identify critical time points within this period for the inhibitory mechanisms identified in this study. A more temporally restricted approach will also allow for additional control measures, such as the inclusion of a CS presented in the absence of neuronal inhibition, to further validate the specificity of our reported effects. On a related front, although our work focuses on the acquisition of new fear memories, the BA has been implicated in the recall and extinction of established fear memories (Herry et al., 2008; Amano et al., 2011), and the implications of our findings to the role played by this brain region in other aspects of fear learning is unclear.

It is also important to note that pyramidal neurons in the BLA complex also receive excitatory input during CS and US presentations (Letzkus et al., 2015). Our demonstration that BA pyramidal neuron inhibition promotes the association between an auditory cue and a behavioral response does not rule out a role for BA pyramidal neuron excitation in associative learning as well. Indeed, the inability of BA pyramidal neuron inhibition to generate a long-term memory in the absence of a discrete CS, and the lack of impact of BA pyramidal neuron inhibition in a weak fear conditioning paradigm (Fig. 7), suggest that other signals shape the resulting fear memory.

Together, our findings demonstrate that inhibitory signaling in the amygdala plays a more diverse and nuanced role in associative learning than originally thought. In combination with previous studies, our work shows that the cellular mechanisms underlying fear learning differ in the LA and BA, with pyramidal neuron excitation promoting memory formation in the former, and pyramidal neuron inhibition serving this role in the latter. It will be important to investigate more extensively the potential role of inhibitory signaling in normal associative learning processes, and in diseases in which these processes are disrupted.

\section{References}

Akagi Jordão EM, Onishi BK, Xavier GF (2015) Pre-training reversible inactivation of the basal amygdala (BA) disrupts contextual, but not auditory, fear conditioning, in rats. PloS One 10:e0125489. CrossRef Medline 
Amano T, Duvarci S, Popa D, Pare D (2011) The fear circuit revisited: contributions of the basal amygdala nuclei to conditioned fear. $J$ Neurosci 31:15481-15489. CrossRef

Amorapanth P, LeDoux JE, Nader K (2000) Different lateral amygdala outputs mediate reactions and actions elicited by a fear-arousing stimulus. Nat Neurosci 3:74-79. CrossRef Medline

Anglada-Figueroa D, Quirk GJ (2005) Lesions of the basal amygdala block expression of conditioned fear but not extinction. J Neurosci 25:9680-9685. CrossRef Medline

Armbruster BN, Li X, Pausch MH, Herlitze S, Roth BL (2007) Evolving the lock to fit the key to create a family of $G$ protein-coupled receptors potently activated by an inert ligand. Proc Natl Acad Sci U S A 104:5163-5168. CrossRef Medline

Arora D, Haluk DM, Kourrich S, Pravetoni M, Fernández-Alacid L, Nicolau JC, Luján R, Wickman K (2010) Altered neurotransmission in the mesolimbic reward system of Girk-/- mice. J Neurochem 114:1487-1497. CrossRef Medline

Beyeler A, Chang CJ, Silvestre M, Lévêque C, Namburi P, Wildes CP, Tye KM (2018) Organization of valence-encoding and projectiondefined neurons in the basolateral amygdala. Cell Rep 22:905918. CrossRef Medline

Beyeler A, Namburi P, Glober GF, Simonnet C, Calhoon GG, Conyers GF, Luck R, Wildes CP, Tye KM (2016) Divergent routing of positive and negative information from the amygdala during memory retrieval. Neuron 90:348-361. CrossRef Medline

Bocchio M, Fucsina G, Oikonomidis L, McHugh SB, Bannerman DM, Sharp T, Capogna M (2015) Increased serotonin transporter expression reduces fear and recruitment of parvalbumin interneurons of the amygdala. Neuropsychopharmacology 40: 3015-3026. CrossRef Medline

Bowers ME, Ressler KJ (2015) An overview of translationally informed treatments for posttraumatic stress disorder: animal models of Pavlovian fear conditioning to human clinical trials. Biol Psychiatry 78:E15-E27. CrossRef Medline

Burgos-Robles A, Kimchi EY, Izadmehr EM, Porzenheim MJ, Ramos-Guasp WA, Nieh EH, Felix-Ortiz AC, Namburi P, Leppla $\mathrm{CA}$, Presbrey KN, Anandalingam KK, Pagan-Rivera PA, Anahtar M, Beyeler A, Tye KM (2017) Amygdala inputs to prefrontal cortex guide behavior amid conflicting cues of reward and punishment. Nat Neurosci 20:824-835. CrossRef Medline

Calandreau L, Desmedt A, Decorte L, Jaffard R (2005) A different recruitment of the lateral and basolateral amygdala promotes contextual or elemental conditioned association in Pavlovian fear conditioning. Learn Mem 12:383-388. CrossRef Medline

Duvarci S, Pare D (2014) Amygdala microcircuits controlling learned fear. Neuron 82:966-980. CrossRef Medline

Fanselow MS, LeDoux JE (1999) Why we think plasticity underlying Pavlovian fear conditioning occurs in the basolateral amygdala. Neuron 23:229-232. Medline

Fanselow MS, Poulos AM (2005) The neuroscience of mammalian associative learning. Annu Rev Psychol 56:207-234. CrossRef Medline

Goosens KA, Maren S (2001) Contextual and auditory fear conditioning are mediated by the lateral, basal, and central amygdaloid nuclei in rats. Learn Mem 8:148-155. CrossRef Medline

Hearing M, Kotecki L, Marron Fernandez de Velasco E, FajardoSerrano A, Chung HJ, Luján R, Wickman K (2013) Repeated cocaine weakens $\mathrm{GABA}(\mathrm{B})$-Girk signaling in layer $5 / 6$ pyramidal neurons in the prelimbic cortex. Neuron 80:159-170. CrossRef Medline

Herry C, Johansen JP (2014) Encoding of fear learning and memory in distributed neuronal circuits. Nat Neurosci 17:1644-1654. CrossRef Medline

Herry C, Ciocchi S, Senn V, Demmou L, Müller C, Lüthi A (2008) Switching on and off fear by distinct neuronal circuits. Nature 454:600-606. CrossRef Medline

Izquierdo I, Furini CR, Myskiw JC (2016) Fear memory. Physiol Rev 96:695-750. CrossRef Medline

Janak PH, Tye KM (2015) From circuits to behaviour in the amygdala. Nature 517:284-292. CrossRef Medline
Johansen JP, Hamanaka H, Monfils MH, Behnia R, Deisseroth K, Blair HT, LeDoux JE (2010) Optical activation of lateral amygdala pyramidal cells instructs associative fear learning. Proc Natl Acad Sci U S A 107:12692-12697. CrossRef Medline

Johansen JP, Cain CK, Ostroff LE, LeDoux JE (2011) Molecular mechanisms of fear learning and memory. Cell 147:509-524. CrossRef Medline

Johansen JP, Diaz-Mataix L, Hamanaka H, Ozawa T, Ycu E, Koivumaa J, Kumar A, Hou M, Deisseroth K, Boyden ES, LeDoux JE (2014) Hebbian and neuromodulatory mechanisms interact to trigger associative memory formation. Proc Natl Acad Sci U S A 111:E5584-E5592. CrossRef Medline

Kim J, Kwon JT, Kim HS, Josselyn SA, Han JH (2014) Memory recall and modifications by activating neurons with elevated CREB. Nat Neurosci 17:65-72. CrossRef Medline

Krettek JE, Price JL (1978) A description of the amygdaloid complex in the rat and cat with observations on intra-amygdaloid axonal connections. J Comp Neur 178:255-280. CrossRef Medline

LeDoux JE (2000) Emotion circuits in the brain. Annu Rev Neurosci 23:155-184. CrossRef Medline

LeDoux JE, Cicchetti P, Xagoraris A, Romanski LM (1990) The lateral amygdaloid nucleus: sensory interface of the amygdala in fear conditioning. J Neurosci 10:1062-1069. Medline

Letzkus JJ, Wolff SB, Lüthi A (2015) Disinhibition: a circuit mechanism for associative learning and memory. Neuron 88:264-276. CrossRef Medline

Letzkus JJ, Wolff SB, Meyer EM, Tovote P, Courtin J, Herry C, Lüthi A (2011) A disinhibitory microcircuit for associative fear learning in the auditory cortex. Nature 480:331-335. CrossRef Medline

Lovett-Barron M, Kaifosh P, Kheirbek MA, Danielson N, Zaremba JD, Reardon TR, Turi GF, Hen R, Zemelman BV, Losonczy A (2014) Dendritic inhibition in the hippocampus supports fear learning. Science 343:857-863. CrossRef Medline

Lucas EK, Clem RL (2018) GABAergic interneurons: the orchestra or the conductor in fear learning and memory? Brain Res Bull 141: 13-19. CrossRef Medline

Lüjan R, Marron Fernandez de Velasco E, Aguado C, Wickman K (2014) New insights into the therapeutic potential of Girk channels. Trends Neurosci 37:20-29. CrossRef Medline

Lüscher C, Slesinger PA (2010) Emerging roles for G protein-gated inwardly rectifying potassium (GIRK) channels in health and disease. Nat Rev Neurosci 11:301-315. CrossRef

Madisen L, Zwingman TA, Sunkin SM, Oh SW, Zariwala HA, Gu H, $\mathrm{Ng}$ LL, Palmiter RD, Hawrylycz MJ, Jones AR, Lein ES, Zeng H (2010) A robust and high-throughput Cre reporting and characterization system for the whole mouse brain. Nat Neurosci 13:133140. CrossRef Medline

Maren S (2001) Neurobiology of Pavlovian fear conditioning. Annu Rev Neurosci 24:897-931. CrossRef Medline

Maren S, Phan KL, Liberzon I (2013) The contextual brain: implications for fear conditioning, extinction and psychopathology. Nat Rev Neurosci 14:417-428. CrossRef Medline

Marron Fernandez de Velasco E, Carlblom N, Xia Z, Wickman K (2017) Suppression of inhibitory G protein signaling in forebrain pyramidal neurons triggers plasticity of glutamatergic neurotransmission in the nucleus accumbens core. Neuropharmacology 117: 33-40. CrossRef Medline

McDonald AJ (1998) Cortical pathways to the mammalian amygdala. Prog Neurobiol 55:257-332. Medline

McDonald AJ, Mott DD (2017) Functional neuroanatomy of amygdalohippocampal interconnections and their role in learning and memory. J Neurosci Res 95:797-820. CrossRef Medline

Nader K, Majidishad P, Amorapanth P, LeDoux JE (2001) Damage to the lateral and central, but not other, amygdaloid nuclei prevents the acquisition of auditory fear conditioning. Learn Mem 8:156163. CrossRef Medline

Namburi P, Beyeler A, Yorozu S, Calhoon GG, Halbert SA, Wichmann R, Holden SS, Mertens KL, Anahtar M, Felix-Ortiz AC, Wickersham IR, Gray JM, Tye KM (2015) A circuit mechanism for 
differentiating positive and negative associations. Nature 520:675678. CrossRef Medline

Nielen MM, den Boer JA, Smid HG (2009) Patients with obsessivecompulsive disorder are impaired in associative learning based on external feedback. Psychol Med 39:1519-1526. CrossRef Medline

Nonaka A, Toyoda T, Miura Y, Hitora-Imamura N, Naka M, Eguchi M, Yamaguchi S, Ikegaya Y, Matsuki N, Nomura H (2014) Synaptic plasticity associated with a memory engram in the basolateral amygdala. J Neurosci 34:9305-9309. CrossRef Medline

Onishi BK, Xavier GF (2010) Contextual, but not auditory, fear conditioning is disrupted by neurotoxic selective lesion of the basal nucleus of amygdala in rats. Neurobiol Learn Mem 93:165-174. CrossRef Medline

Pape HC, Pare D (2010) Plastic synaptic networks of the amygdala for the acquisition, expression, and extinction of conditioned fear. Physiol Rev 90:419-463. CrossRef Medline

Rainnie DG, Asprodini EK, Shinnick-Gallagher P (1993) Intracellular recordings from morphologically identified neurons of the basolateral amygdala. J Neurophysiol 69:1350-1362. CrossRef Medline

Romanski LM, Clugnet MC, Bordi F, LeDoux JE (1993) Somatosensory and auditory convergence in the lateral nucleus of the amygdala. Behav Neurosci 107:444-450. Medline

Roth BL (2016) DREADDs for neuroscientists. Neuron 89:683-694. CrossRef Medline

Rozeske RR, Valerio S, Chaudun F, Herry C (2015) Prefrontal neuronal circuits of contextual fear conditioning. Genes Brain Behav 14:22-36. CrossRef Medline

Sah P, Faber ES, Lopez De Armentia M, Power J (2003) The amygdaloid complex: anatomy and physiology. Physiol Rev 83:803834. CrossRef Medline

Smith Y, Paré D (1994) Intra-amygdaloid projections of the lateral nucleus in the cat: PHA-L anterograde labeling combined with postembedding GABA and glutamate immunocytochemistry. J Comp Neur 342:232-248. CrossRef Medline

Sonner JM, Cascio M, Xing Y, Fanselow MS, Kralic JE, Morrow AL, Korpi ER, Hardy S, Sloat B, Eger El 2nd, Homanics GE (2005) Alpha 1 subunit-containing GABA type $A$ receptors in forebrain contribute to the effect of inhaled anesthetics on conditioned fear. Mol Pharmacol 68:61-68. CrossRef Medline

Sosulina L, Meis S, Seifert G, Steinhäuser C, Pape HC (2006) Classification of projection neurons and interneurons in the rat lateral amygdala based upon cluster analysis. Mol Cell Neurosci 33:5767. CrossRef Medline

Spampanato J, Polepalli J, Sah P (2011) Interneurons in the basolateral amygdala. Neuropharmacology 60:765-773. CrossRef Medline

Taniguchi H, He M, Wu P, Kim S, Paik R, Sugino K, Kvitsiani D, Fu Y, Lu J, Lin Y, Miyoshi G, Shima Y, Fishell G, Nelson SB, Huang ZJ (2011) A resource of Cre driver lines for genetic targeting of
GABAergic neurons in cerebral cortex. Neuron 71:995-1013. CrossRef Medline

Taylor JR, Torregrossa MM (2015) Pharmacological disruption of maladaptive memory. Handb Exp Pharmacol 228:381-415. CrossRef Medline

Tipps ME, Raybuck JD, Buck KJ, Lattal KM (2014) Delay and trace fear conditioning in C57BL/6 and DBA/2 mice: issues of measurement and performance. Learn Mem 21:380-393. CrossRef Medline

Tsien JZ, Chen DF, Gerber D, Tom C, Mercer EH, Anderson DJ, Mayford M, Kandel ER, Tonegawa S (1996) Subregion- and cell type-restricted gene knockout in mouse brain. Cell 87:1317-1326. Medline

Vereczki VK, Veres JM, Müller K, Nagy GA, Rácz B, Barsy B, Hájos $N$ (2016) Synaptic organization of perisomatic GABAergic inputs onto the principal cells of the mouse basolateral amygdala. Front Neuroanat 10:20. CrossRef Medline

Veres JM, Nagy GA, Vereczki VK, Andrási T, Hájos N (2014) Strategically positioned inhibitory synapses of axo-axonic cells potently control principal neuron spiking in the basolateral amygdala. $J$ Neurosci 34:16194-16206. CrossRef Medline

Veres JM, Nagy GA, Hajos N (2017) Perisomatic GABAergic synapses of basket cells effectively control principal neuron activity in amygdala networks. eLife 6:e20721. CrossRef Medline

Victoria NC, Marron Fernandez de Velasco E, Ostrovskaya O, Metzger S, Xia Z, Kotecki L, Benneyworth MA, Zink AN, Martemyanov KA, Wickman K (2016) G protein-gated K+ channel ablation in forebrain pyramidal neurons selectively impairs fear learning. Biol Psychiatry 80:796-806. CrossRef

Wolff SB, Gründemann J, Tovote P, Krabbe S, Jacobson GA, Müller C, Herry C, Ehrlich I, Friedrich RW, Letzkus JJ, Lüthi A (2014) Amygdala interneuron subtypes control fear learning through disinhibition. Nature 509:453-458. CrossRef Medline

Woodruff AR, Sah P (2007) Inhibition and synchronization of basal amygdala principal neuron spiking by parvalbumin-positive interneurons. J Neurophysiol 98:2956-2961. CrossRef Medline

Yiu AP, Mercaldo V, Yan C, Richards B, Rashid AJ, Hsiang HL, Pressey J, Mahadevan V, Tran MM, Kushner SA, Woodin MA, Frankland PW, Josselyn SA (2014) Neurons are recruited to a memory trace based on relative neuronal excitability immediately before training. Neuron 83:722-735. CrossRef Medline

Zelikowsky M, Hersman S, Chawla MK, Barnes CA, Fanselow MS (2014) Neuronal ensembles in amygdala, hippocampus, and prefrontal cortex track differential components of contextual fear. $J$ Neurosci 34:8462-8466. CrossRef

Zhou Y, Won J, Karlsson MG, Zhou M, Rogerson T, Balaji J, Neve R, Poirazi P, Silva AJ (2009) CREB regulates excitability and the allocation of memory to subsets of neurons in the amygdala. Nat Neurosci 12:1438-1443. CrossRef Medline 